\title{
Deciphering common and specific transcriptional immune responses in pea towards the oomycete pathogens Aphanomyces euteiches and Phytophthora pisi
}

\author{
Sara Hosseini, Malin Elfstrand, Fredrik Heyman, Dan Funck Jensen and Magnus Karlsson
}

\begin{abstract}
Background: Root rot caused by Aphanomyces euteiches is one of the most destructive pea diseases while a distantly related species $P$. pisi has been recently described as the agent of pea and faba bean root rot. These two oomycete pathogens with different pathogenicity factor repertories have both evolved specific mechanisms to infect pea. However, little is known about the genes and mechanisms of defence against these pathogens in pea. In the present study, the transcriptomic response of pea to these two pathogens was investigated at two time points during early phase of infection using a Medicago truncatula microarray.

Results: Of the 37,976 genes analysed, 574 and 817 were differentially expressed in response to A. euteiches at 6 hpi and 20 hpi, respectively, while 544 and 611 genes were differentially regulated against P. pisi at 6 hpi and 20 hpi, respectively. Differentially expressed genes associated with plant immunity responses were involved in cell wall reinforcement, hormonal signalling and phenylpropanoid metabolism. Activation of cell wall modification, regulation of jasmonic acid biosynthesis and induction of ethylene signalling pathway were among the common transcriptional responses to both of these oomycetes. However, induction of chalcone synthesis and the auxin pathway were specific transcriptional changes against A. euteiches.

Conclusions: Our results demonstrate a global view of differentially expressed pea genes during compatible interactions with $P$. pisi and A. euteiches at an early phase of infection. The results suggest that distinct signalling pathways are triggered in pea by these two pathogens that lead to common and specific immune mechanisms in response to these two oomycetes. The generated knowledge may eventually be used in breeding pea varieties with resistance against root rot disease.
\end{abstract}

Keywords: Hormonal signalling, Microarray, Phenylpropanoid pathway, Pisum sativum, Plant immunity, Resistance gene, Transcriptional response

\section{Background}

Legumes are important sources of proteins for human food and animal feed. In addition, legumes improve soil fertility and decrease the need for $\mathrm{N}$ fertilizers through symbiotic interactions with nitrogen fixing bacteria and thus contribute to the sustainability of agriculture [1]. Field pea, Pisum sativum, is a legume crop that is grown

\footnotetext{
* Correspondence: Sara.Hosseini@slu.se

Department of Forest Mycology and Plant Pathology, Uppsala BioCenter, Swedish University of Agricultural Sciences, Box 7026, SE-75007, Uppsala, Sweden
}

on over 25 million acres worldwide and in Europe dry pea production is the highest within legume production. The main threat to pea yields are diseases, including Aphanomyces euteiches [2] that causes seedling damping off and root rot disease of many legumes. It is considered as the most devastating pea pathogen, causing up to $80 \%$ losses each year $[3,4]$. It is widespread in North America, Europe, Japan, Australia and New Zealand [5, 6]. Phytophthora pisi is a recently described species, which causes root rot on pea and faba bean (Vicia faba), and is capable of infecting certain other legumes closely related 
to these crops [7]. As an emerging pathogen, it represents a potential threat for pea cultivation.

Both these pathogens are oomycetes, which belong to the kingdom Stramenopila and are evolutionary related to brown algae. In the asexual stage bi-flagellated motile zoospores are released in the soil, swim chemotactically towards the plant roots, encyst at the root surface, germinate and subsequently infect the host roots. In the sexual cycle, thick-wall oospores are formed that survive in the soil for many years as the primary source of inoculum. Efficient chemical control of the pea root rot diseases caused by $A$. euteiches and $P$. pisi is not available and crop rotation and other cultural practices remain the only solutions to avoid the disease. Although the use of resistant pea varieties would be the most economical and ecological strategy to control the disease, no resistant variety to either pathogen is commercially available so far.

Pisum sativum has a large and complex genome and currently few comprehensive genomic resources exist. The lack of a sequenced genome is a limiting factor for molecular and -omics approaches for research on this plant [8]. However, the advantage of knowledge and tools available for the legume model species Medicago truncatula are used for research on pea [9-11] since high level of genetic homology and synteny between these two species are reported [12, 13]. A M. truncatula microarray was recently used successfully to study the transcriptomic response of pea during infection by Mycosphaerella pinodes [14].

Our present understanding of the early molecular interactions between A. euteiches or P. pisi and pea are very limited. Plant-pathogen interaction is viewed as a multi-layered process, where in the first layer of the defence system plants can recognize conserved microbeor pathogen-associated molecular patterns (MAMPs or PAMPs) and initiate pattern-triggered immunity (PTI) [15]. Specialized pathogens secrete proteins called effectors that suppress PTI and result in effector-triggered susceptibility (ETS). Subsequently, certain plants recognize particular effectors, or their activity, by resistance (R) proteins, which lead to activation of the second layer of defence, effector-triggered immunity (ETI) $[16,17]$. ETI is stronger in amplitude than PTI and can involve the same or different signalling sectors than PTI, but both layers involve massive changes of gene activity and extensive reprogramming of the cell metabolism.

For a successful defence the activation of plant responses must be rapid, efficient and targeted. It is shown that the signalling sectors defined by the phytohormones salicylic acid (SA), jasmonic acid (JA) and ethylene (ET) are important in plant immunity [18]. SA is generally involved in immunity against biotrophic and hemi-biotrophic pathogens, while the JA and ET sectors are involved in immunity against necrotrophic pathogens and herbivorous insects. Other phytohormones such as abscisic acid, auxin and gibberellins are also involved in plant immune signalling [19]. In addition, a number of phenylpropanoid compounds with antimicrobial activity have been shown to restrict pathogen growth [20, 21]. In legumes, flavonoid compounds that are crucial in the initiation of symbiotic interactions with rhizobia also play a role as defence compounds and as signalling molecules [22]. Aphanomyces spp. belongs to Saprolegniales and includes numerous destructive plant and animal pathogens, whereas Phytophthora spp. belongs to Peronosporales and includes species only pathogenic to plants. This diversity within the oomycetes reflects different evolutionary histories and different mechanisms of infection between Saprolegniales and Peronosporales [23]. One major difference between Aphanomyces and Phytophthora is depicted in their effector repertoires, where Phytophthora species contain a large spectrum of RXLR effectors while no RXLR genes are identified in the A. euteiches genome [24]. Despite being distantly related species, $A$. euteiches and $P$. pisi have both evolved specific pathogenicity on pea as a common host. Therefore, we hypothesize that $A$. euteiches and $P$. pisi manipulate the PTI or ETI defence signalling in pea in common and distinct ways depending on differences in their effector repertories, which subsequently leads to activation of common or distinct pea defence responses.

The aim of this project was to study the transcriptomic response of pea plants towards $A$. euteiches and $P$. pisi during the initial phase of infection, using heterologous probing on a $M$. truncatula microarray. We aim to identify differentially regulated genes during early infection, to make inferences about pea immune-related pathways that are commonly or specifically regulated during interaction with these two oomycetes pathogens.

\section{Results}

\section{Infection process evaluation}

The infection process of pea roots with $A$. euteiches and $P$. pisi was evaluated by analysing gene expression of selected defence marker genes such as ACO (1-aminocyclopropane-1-carboxylate oxidase), Pi49 (PR10-like), ABA17 (abscisic acid responsive gene) and chit4 (chitinase 4), using reverse transcription quantitative PCR (RT-qPCR). Relative expression of all genes increased with time during infection (Additional file 1). Expression of $A C O, A B A 17$ and Pi49 were significantly $(P \leq 0.05)$ induced during $A$. euteiches infection from $20 \mathrm{~h}$ post inoculation (hpi) and onwards, and at 48 hpi during $P$. pisi infection. Infection samples at 6 and $20 \mathrm{hpi}$ were selected to study the early global transcriptomic response of pea to $A$. euteiches and $P$. pisi, using microarray technology. 


\section{Microarray analysis}

\section{Number of differentially expressed genes}

All 40425 probe sequences (37976 genes) included on the microarray showed an analysable signal. Applying the linear models for microarray data (Limma model) [25], 2179 and 3193 genes were identified as responsive to $A$. euteiches at $6 \mathrm{hpi}$ and $20 \mathrm{hpi}$, respectively, while 1610 and 1826 genes were found as responsive to $P$. pisi at $6 \mathrm{hpi}$ and 20 hpi, respectively $(P \leq 0.05)$ (Table 1 , Additional files 2 and 3 ). These lists of responsive genes to each treatment were used for analysis of biochemical pathways in the Kyoto Encyclopedia of Genes and Genomes (KEGG) database. In order to focus the analysis on the genes with higher fold change expression compared to the control samples we considered a cut off $(\geq 0.584)$ on the $\log _{2}$ ratio fold change expression treatment/control of the genes with $P \leq 0.05$. Therefore, genes with $\geq 1.5$ fold induction and $\leq 0.67$ fold suppression compared to control samples in the same time point were defined as differentially expressed genes. In response to A. euteiches, 574 and 817 genes were differentially expressed $\left(P \leq 0.05\right.$ and $\log _{2}$ ratio $\geq 0.584$ ) at $6 \mathrm{hpi}$ and $20 \mathrm{hpi}$, respectively (Table 1 , Fig. 1a, Additional file 2). In response to P. pisi, 544 and 611 sequences were differentially expressed $(P \leq 0.05$ and $\log _{2}$ ratio $\geq 0.584$ ) at $6 \mathrm{hpi}$ and $20 \mathrm{hpi}$, respectively, compared to the control samples at the same time point (Table 1, Fig. 1a, Additional file 3). All differentially expressed genes were associated with their respective Gene Ontology (GO) terms and clustered based on their GO terms. Sixty-four percent of all differentially expressed genes were successfully associated with a GO number and categorized across the three main GO categories of biological process, cellular component and molecular function (Additional file 4). The remaining $36 \%$ represented sequences of currently unknown functions.

\section{Distinct transcriptional plant responses are featured during the early phase of infections by P. pisi and A. euteiches}

The overlap of differentially expressed genes in response to A. euteiches and $P$. pisi over time was determined (Fig. 1b, c). Only a limited number of common genes were up regulated or down regulated in response to the two pathogens at 6 and 20 hpi. In contrast, large sets of genes were uniquely regulated in response to each pathogen and at each time point.

Furthermore, hierarchical clustering was performed for genes differentially regulated in at least one interaction. Four major clusters could be distinguished (Fig. 2). Clusters 1 and 2 represented genes mainly induced at 6 hpi in response to $P$. pisi and $A$. euteiches, respectively. Clusters 3 and 4 included genes mainly induced at $20 \mathrm{hpi}$ in response to $A$. euteiches and $P$. pisi, respectively. Each cluster could be further divided into smaller sub-clusters containing genes with common regulatory patterns (Fig. 2, Additional file 5). Sub-clusters $1 \mathrm{~b}$ and $2 \mathrm{a}$ included genes induced in response to both pathogens at $6 \mathrm{hpi}$, while sub-clusters $1 \mathrm{a}$ and $2 \mathrm{~b}$ included genes specifically induced in response to $P$. pisi and $A$. euteiches at $6 \mathrm{hpi}$, respectively. Sub-clusters $3 \mathrm{~b}$ and $4 \mathrm{a}$ included genes induced in response to both pathogens at $20 \mathrm{hpi}$, while sub-clusters $3 \mathrm{a}$ and $4 \mathrm{~b}$ represented genes specifically induced at $20 \mathrm{hpi}$ in response to A. euteiches and P. pisi, respectively (Fig. 2, Additional file 5).

The combined genes present in clusters 1 and 2 were significantly $(P \leq 0.005)$ enriched in five molecular functions and six cellular component GO categories compared with the combined genes present in clusters 3 and 4. The enriched molecular functions in clusters 1 and 2, which are mainly those induced at $6 \mathrm{hpi}$, were associated with antioxidant activity (GO:0016209), peroxidase activity (GO:0004601) and peptidase activity (GO:0008234/ GO:0004197) as well as cellular component ontologies associated with cell (GO:0005623) and plant-type cell wall (GO:0009505) (Additional file 6). However, the combined genes present in clusters 3 and 4, or any combination of sub-clusters, were not enriched in any functional categories.

\section{Phytophthora pisi and A. euteiches infections lead to disparate pathogen perception and signalling transcriptomic responses in pea}

To investigate transcriptional changes in gene classes involved in pathogen perception and signalling, genes with GO number associated with the signal transduction process (GO:0007165) were identified. In total, 89 differentially regulated genes were found among all data sets. Hierarchical clustering of genes associated with signal

Table 1 Number of genes related to each treatment in response to Aphanomyces euteiches and Phytophthora pisi at 6 hpi and 20 hpi

\begin{tabular}{|c|c|c|c|c|c|c|c|c|}
\hline \multirow[t]{2}{*}{ Gene sets } & \multicolumn{2}{|c|}{ A. euteiches $6 \mathrm{hpi}$} & \multicolumn{2}{|c|}{ A. euteiches 20 hpi } & \multicolumn{2}{|c|}{ P. pisi 6 hpi } & \multicolumn{2}{|c|}{ P. pisi 20 hpi } \\
\hline & $U p^{a}$ & Down $^{a}$ & Up & Down & Up & Down & Up & Down \\
\hline Genes responsive to the treatment ${ }^{b}$ & 1120 & 1059 & 1506 & 1687 & 797 & 813 & 919 & 907 \\
\hline Differentially expressed genes ${ }^{c}$ & 254 & 320 & 466 & 351 & 310 & 234 & 324 & 287 \\
\hline
\end{tabular}

${ }^{a} U p$ and Down refers to the up regulated and down regulated genes, respectively

${ }^{\mathrm{b}}$ Refers to the genes with a $P$ value $\leq 0.05$ in response to the pathogen compared to the control samples at the same time point

${ }^{c}$ Refers to the genes with a $P$ value $\leq 0.05$ and the $\log _{2}$ ratio $\geq 0.584$ ( $>1.5$ fold induction or $\leq 0.67$ repression) compared to the control samples at the same time point 


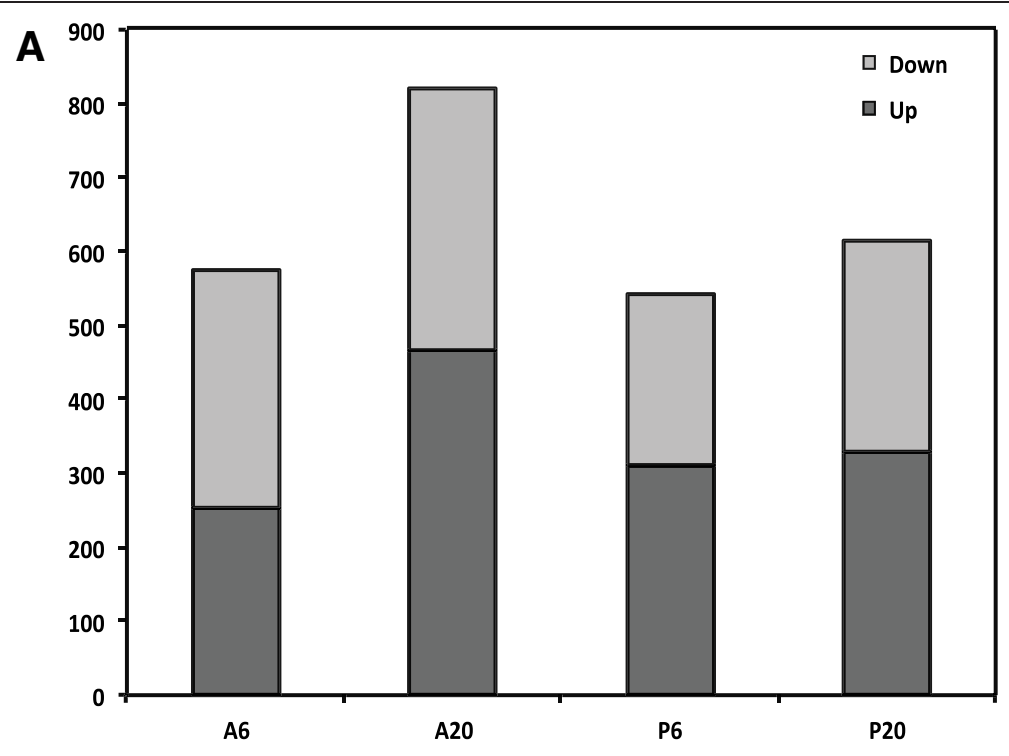

B
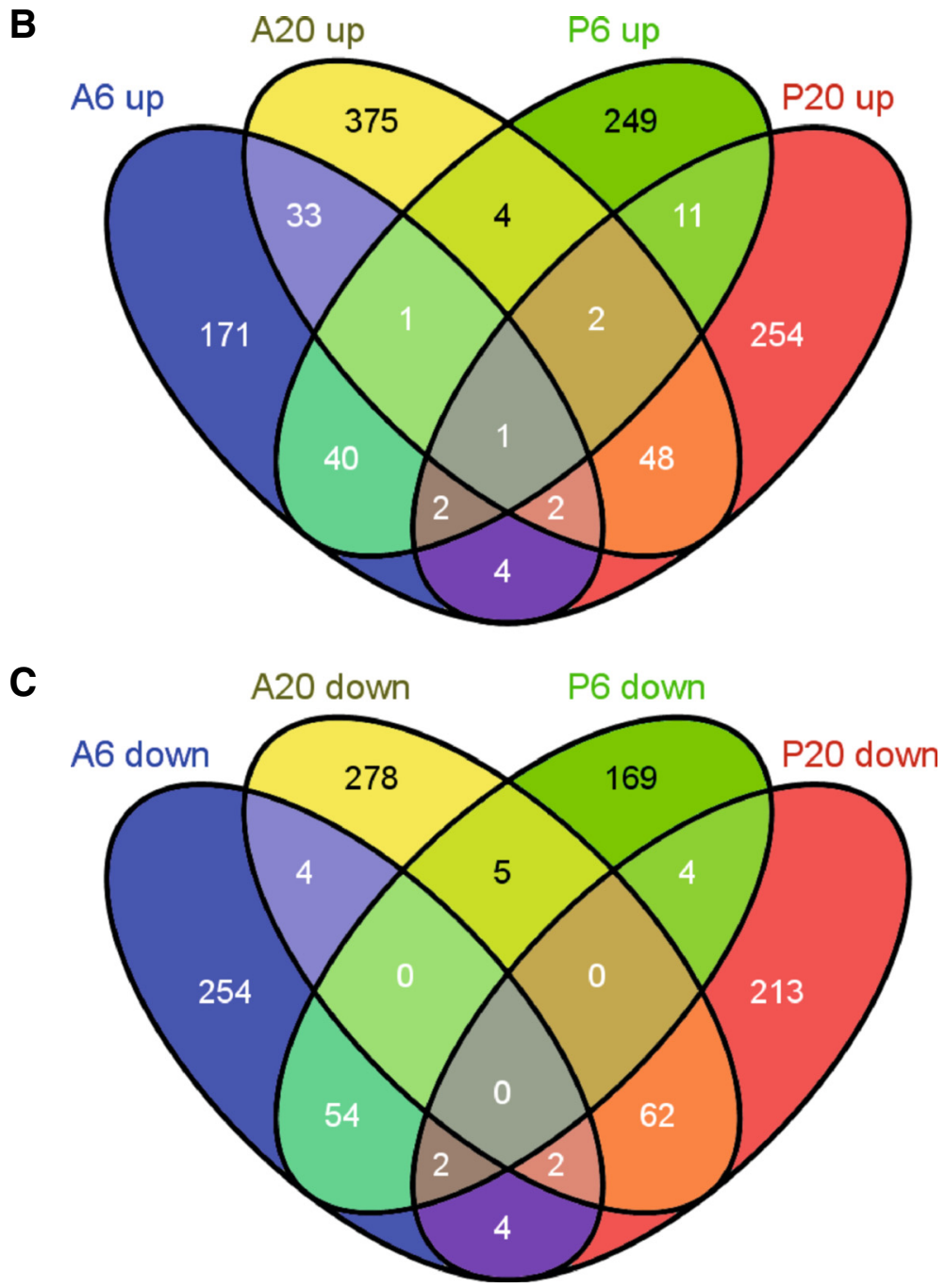

Fig. 1 (See legend on next page.) 
(See figure on previous page.)

Fig. 1 Number of differentially expressed pea genes during interaction with A. euteiches and $P$. pisi, and the overlap between time points and species. a Overview of the number of significantly up regulated (dark grey) and down regulated (light grey) genes compared to the control samples at each time point of infection. The overlap between (b) up regulated and (c) down regulated gene sets

transduction showed four distinguished clusters, similar to those of all differentially expressed genes. The clusters represented genes uniquely induced in response to each pathogen at different time points and genes activated in common for both pathogens (Fig. 3a, Additional file 7). Cluster 1 represented a set of 40 genes that were induced at $6 \mathrm{hpi}$ in response to both pathogens, but suppressed at $20 \mathrm{hpi}$. Cluster 2 represented 15 genes that were significantly induced at $6 \mathrm{hpi}$ in response to $A$. euteiches and cluster 3 represented genes induced at 20 hpi in response to $P$. pisi while cluster 4 includes the genes all specifically up-regulated in response to $A$. euteiches at $20 \mathrm{hpi}$ (Additional file 7). The overlap between differentially expressed genes associated with signal transduction in response to $A$. euteiches and $P$. pisi over time was determined (Fig. 3b). A majority of the genes were specifically up regulated or down regulated at each time points in response to each pathogen.

Among the genes associated with signal transduction, 41 were identified as putative $R$-genes and receptor-like kinases (RLK-genes) (Additional file 7). Hierarchical clustering of these genes revealed two clusters. Cluster 1 represented genes induced at 6 hpi while suppressed at 20 hpi. Cluster 2 included two subclasses in which subclass 2a represented genes that were suppressed at 6 hpi while induced at $20 \mathrm{hpi}$ in response to both species while cluster $2 \mathrm{~b}$ included genes that were specifically induced or suppressed at each time point responding to the pathogens (Fig. 4). Twelve and ten putative $R$ - and $R L K S$-genes were down regulated at both time points upon infection with $A$. euteiches and $P$. pisi, respectively, and may thus represent potential targets of defence-suppressing pathogen effectors.

\section{Phytophthora pisi and A. euteiches infections result in differential expression of defence related genes in phenylpropanoid and hormonal pathways}

Downstream pea immune responses were investigated by mapping all genes to KEGG pathways and by grouping genes into two sets previously reported to be involved in plant immune responses: the phenylpropanoid pathway and biosynthesis of secondary metabolites, and hormonal signalling.

Phenylpropanoid pathway and biosynthesis of secondary metabolites The gene AC148816_15.4, putatively encoding a shikimate O-hydroxycinnamoyltransferase (HCT; EC: 2.3.1.133) was induced 2.8 fold at 6 hpi in response to $P$. pisi. Five putative chalcone synthases (CHS; EC: 2.3.1.74), AC146575_11.5, AC146575_16.5,
AC137823_12.5, AC146575_32.5 and AC146571_8.4) involved in the early steps of flavonoid biosynthesis, were up regulated at $20 \mathrm{hpi}$ in response to A. euteiches (from 1.6 to 2.4 fold), but not induced in response to $P$. pisi. The putative isoflavone 7-O-methyltransferase (I7OMT; EC: 2.1.1.150) AC139852_38.4, which presumably methylates 7,4-dihydroxyiso-flavone (daidzein) and 5,7,4-trihydroxyisoflavone (genistein) to yield isoformononetin and prunetin, was suppressed 2 fold (ratio treatment/control $=0.5$ ) at $20 \mathrm{hpi}$ in response to A. euteiches (Fig. 5).

Genes involved in cell wall modifications were also differentially regulated. The gene CR931741_28.4, putatively encoding a cinnamyl-alcohol dehydrogenase (CAD; EC: 1.1.1.195) that is responsible for the last enzymatic step in the monolignol biosynthesis, was induced 1.7 fold at $20 \mathrm{hpi}$ in response to both pathogens, while another member of this gene family, CR931741_7.4 was suppressed 2.6 fold at $6 \mathrm{hpi}$ in response to $P$. pisi (Fig. 5). Furthermore, two putative callose synthases (GSL; EC: 2.4.1.34) AC155803_41.5 and AC137603_39.4, were up regulated 1.6 fold at 6 hpi in response to $P$. pisi and $A$. euteiches, respectively. However, at 20 hpi GSL AC155803_41.5 showed suppression by 2 fold in response to both pathogens (Table 2). Several putative pectin esterase (EC: 3.1.1.11) genes were differentially expressed; two different genes, AC174141_27.4 and CT009653_39.4, were induced 1.5 and 1.7 fold against $A$. euteiches at 6 and $20 \mathrm{hpi}$, respectively, while three other genes were suppressed upon infection by P. pisi (AC150204_16.5 at 6 hpi, AC153005_9.5 and CT009653_39.4 at 20 hpi). The gene AC173289_18.5, encoding a putative pectin esterase inhibitor enzyme (EC: 3.1.1.11) predicted to prevent or reduce the activity of pectin esterases, was induced at $20 \mathrm{hpi} 1.6$ and 1.7 fold during interaction with $A$. euteiches and P. pisi, respectively (Table 2 ).

Hormonal signalling At 6 hpi the gene AC155803_43.5, putatively encoding a lipoxygenase (LOX; EC: 1.13.11.12) that is involved in the biosynthesis of JA, was suppressed by 1.6 fold in response to both pathogens while two other members of this gene family, AC146571_7.4 and AY515253_32.4, were induced at $20 \mathrm{hpi}$ in response to $P$. pisi and A. euteiches by 2.3 and 1.5 fold, respectively. Two (AC169513_37.4 and AC125389_65.5) and three (AC146817_41.4, AC174337_15.4 and AC202309_24.3) putative $A C O$ genes, involved in the final step of ET production, were up regulated upon infection with $P$. 


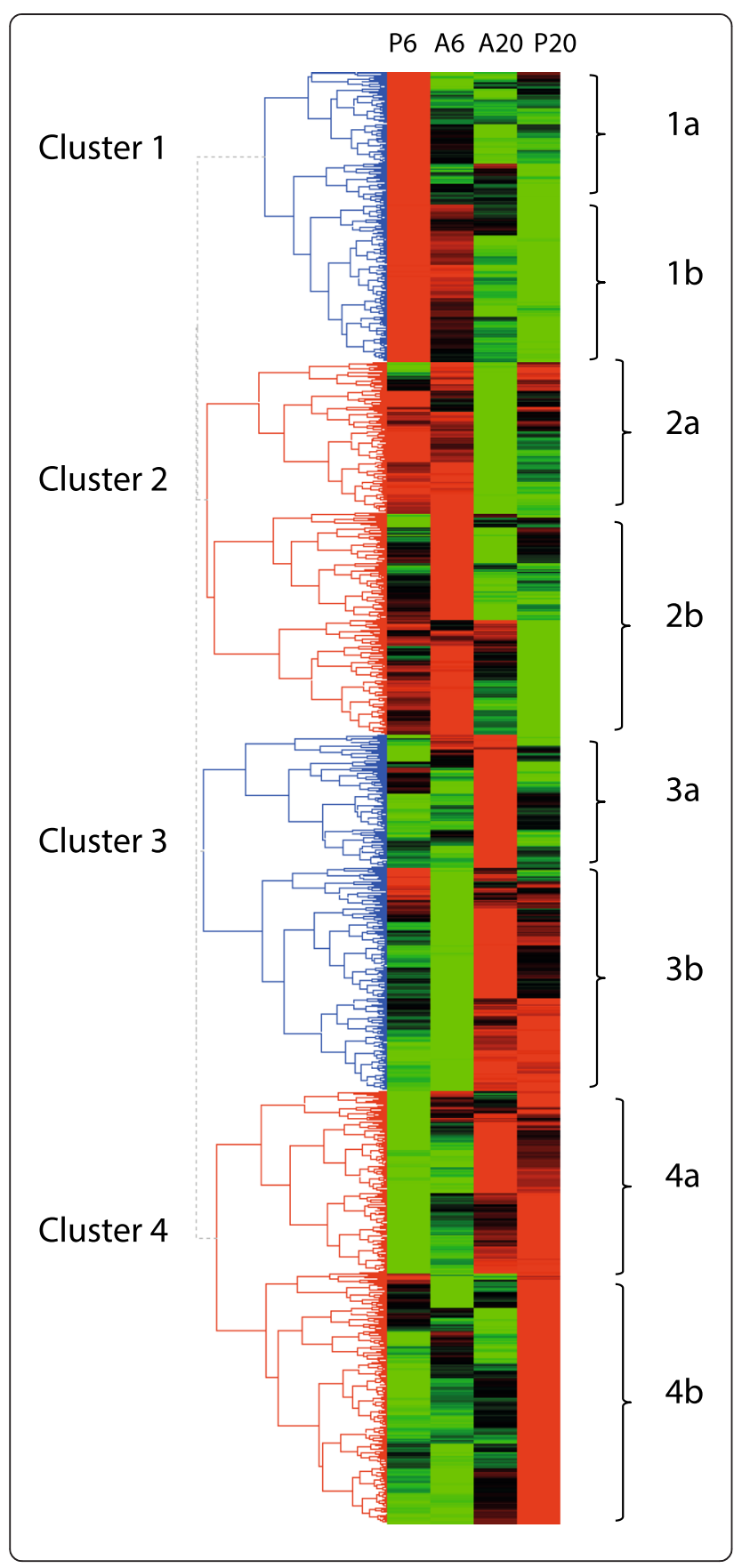

Fig. 2 Clustering of differentially expressed pea genes in response to $A$. euteiches and $P$. pisi. Hierarchical clustering of all differentially expressed genes ( $P \leq 0.05, \geq 1.5$ fold induction or $\leq 0.67$ fold repression) at 6 hpi and 20 hpi compared to the mock-inoculated control samples generated by HCE3.5 software with the complete linkage method and the Manhattan distance measure. Red and green represent up regulated and down regulated genes, respectively. Four classes of genes were defined according to their expression profiles. Cluster 1 and 4 corresponds to genes highly up regulated at $6 \mathrm{hpi}$ and $20 \mathrm{hpi}$ in response to P. pisi (P6 and P20, respectively), while cluster 2 and 3 corresponds to genes up regulated at $6 \mathrm{hpi}$ and $20 \mathrm{hpi}$ in response to A. euteiches (A6 and A20, respectively). Each cluster was urther divided into smaller sub-clusters containing genes with common regulatory patterns. Sub-clusters $1 \mathrm{~b}$ and $2 \mathrm{a}$ included genes induced in response to both pathogens at $6 \mathrm{hpi}$, while sub-clusters $1 \mathrm{a}$ and $2 \mathrm{~b}$ included genes specifically induced in response to P. pisi and $A$. euteiches at 6 hpi, respectively. Sub-clusters $3 \mathrm{~b}$ and $4 \mathrm{a}$ included genes induced in response to both pathogens at $20 \mathrm{hpi}$, while sub-clusters $3 \mathrm{a}$ and $4 \mathrm{~b}$ represented genes specifically induced at $20 \mathrm{hpi}$ in response to $A$. euteiches and $P$. pisi, respectively

pisi at 6 and $20 \mathrm{hpi}$, respectively (from 1.5 to 2.9 fold). In contrast, two other putative $A C O$ genes, AC169513_37.4 and AC169513_37.4, showed 1.8 fold inductions in response to A. euteiches at $6 \mathrm{hpi}$ and 20 hpi, respectively. The AC145767_15.4 gene that is a putative ethylene-responsive transcription factor (ERF) gene, essential for ET biosynthesis [26], showed 1.6 fold induction at 20 hpi against $A$. euteiches only. Three putative auxin-induced SAUR family member genes (CU326390_14.3, AC148242_50.4 and AC146705_13.5), known to be rapidly and transiently up regulated in response to auxin $[27,28]$, were induced against $A$. euteiches at 20 hpi (by 1.9 fold) but constitutively expressed against $P$. pisi (Table 3).

\section{Confirmation and investigation of differential gene expression by quantitative PCR}

RT-qPCR was used to validate the microarray data and to assess the expression levels of seven selected candidate genes in pea during interaction with $P$. pisi and $A$. euteiches at $2 \mathrm{hpi}, 6 \mathrm{hpi}, 20 \mathrm{hpi}$ and $48 \mathrm{hpi}$. The genes were chosen to include genes specifically induced, suppressed and non-regulated in response to A. euteiches, and to cover several different functional categories. The expression patterns observed by RT-qPCR were in agreement with those obtained by microarray at $6 \mathrm{hpi}$ and 20 hpi (Fig. 6). The only exception was that the pea OMT gene, which showed similarity (E-value 0.0 and $72 \%$ identity) to the $M$. truncatula I7OMT involved in methylation of daidzein and genistein, was down regulated at $20 \mathrm{hpi}$ in response to A. euteiches according to the microarray experiment but up regulated at this time according to RT-qPCR $(P<0.001)$. The expression pattern of the HMM6 gene, putatively encoding a 6ahydroxymaackiain methyltransferase enzyme that catalyses 


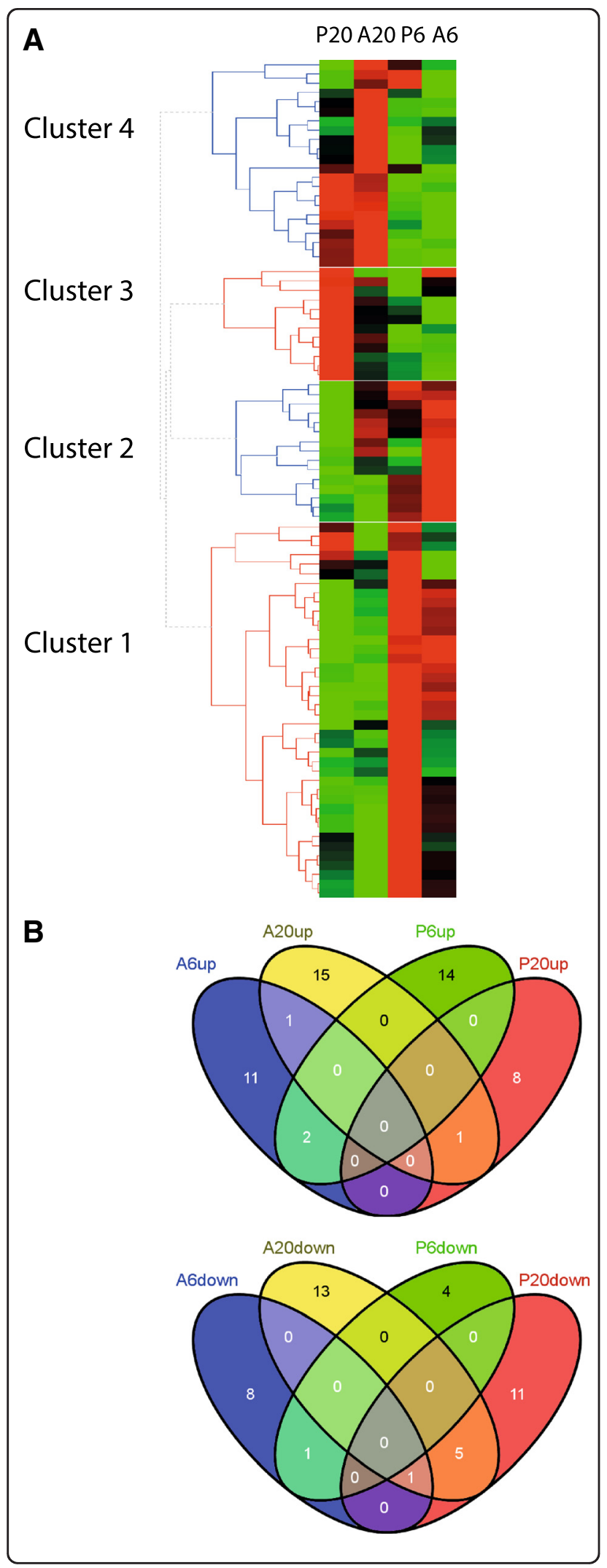

Fig. 3 Differentially expressed pea immune signalling candidate genes. a Hierarchical clustering of differentially expressed genes ( $P \leq 0.05, \geq 1.5$ fold induction or $\leq 0.67$ fold repression) that corresponds to pathogen perception and signalling during early time of interaction with $A$. euteiches and P. pisi. The clustering is generated by HCE3.5 software with the complete linkage method and the Manhattan distance measure. Red and green represent up regulated and down regulated genes, respectively. $\mathrm{P} 6$ and $\mathrm{P} 20$ correspond to infection by P. pisi at 6 and 20 hpi, while A6 and A20 correspond to infection by $A$. euteiches at 6 and 20 hpi, respectively. The overlap between (b) up regulated and (c) down regulated gene sets associated with immune signalling is shown

the last step of the synthesis of the main pea phytoalexin pisatin, was investigated by RT-qPCR although no data was available for this gene in the microarray experiment. The result showed up-regulation of this gene against $A$. euteiches at 20 hpi compared to the control, followed by 10 fold induction at $48 \mathrm{hpi}$ compared to $2 \mathrm{hpi}(P \leq 0.029)$.

In response to $A$. euteiches, the putative chalcone synthase genes CHS1 and CHS2 were induced 10 fold compared to the control at 20 hpi $(P \leq 0.006)$, while they were constitutively expressed during $P$. pisi infection. The GSL1 gene, putatively encoding a callose synthase, was induced at 2 hpi specifically in interaction with $P$. pisi $(P<0.007)$. The POD1 gene putatively encoding a peroxidase was specifically induced during the $2-20 \mathrm{hpi}$ interaction with $A$. euteiches $(P \leq 0.007)$ while only induced at $48 \mathrm{hpi}$ in response to $P$. pisi $(P=0.009)$. The $N B$ $L R R 1$ gene, putatively encoding a nucleotide binding-site leucine-rich repeat protein, was specifically suppressed by $6 \mathrm{hpi}$ after $A$. euteiches infection and later during that interaction $(P \leq 0.012)$. The expression of the LOX1 gene, putatively encoding a linoleate 13S-lipoxygenase, was up regulated early after infection with $P$. pisi (at 2 hpi, $P=0.010$ ) while constitutively expressed later during infection with both pathogens.

\section{Discussion}

Our previous characterization of the infection process of $P$. pisi on pea roots suggests that the infection process turns necrotrophic by 27 hpi [29]. However, haustorium formation in the prospective biotrophic phase is not reported in either $A$. euteiches or $P$. pisi. Based on the significant gene expression induction of defence marker genes Pi49, ABA17, ACO and chit4 [30,31] at 20 and 48 $\mathrm{hpi}$, and the evaluation of the infection process in a previous study [29], pea roots at 6 and 20 hpi were sampled for the transcriptomic analysis to represent early infection.

A number of reference genomes for legumes including M. truncatula, Glycine max and Phaseolus vulgaris are completed [32-34], but the genome of pea has not yet been sequenced and this limits the usefulness of deep sequencing approaches for transcriptomic investigations. An approach to study the transcriptional responses in 


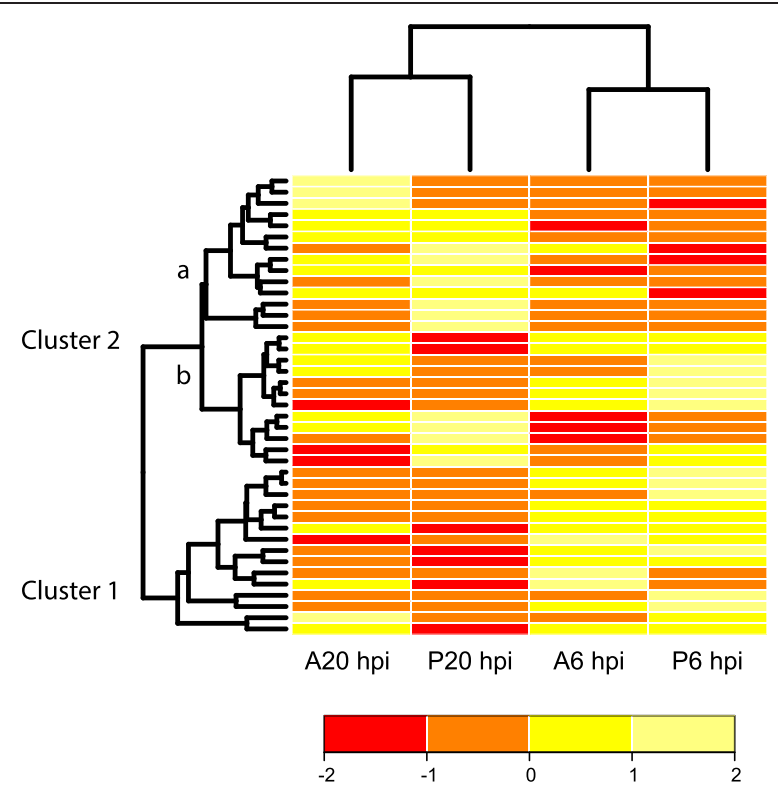

Fig. 4 Differentially expressed pea resistance genes. Hierarchical clustering of differentially expressed pea $N B-L R R$ and $R L K$ genes $(P \leq 0.05, \geq 1.5$ fold induction or $\leq 0.67$ fold repression) during early time of interaction with $A$. euteiches $(A)$ and $P$. pisi $(P)$. The clustering is generated in $R$ software. Yellow and red represent up regulated and down regulated genes, respectively

species lacking genome sequence information is heterologous probing on microarrays based on closely related species, which is successfully used for pea by hybridization on a $M$. truncatula microarray [14].

Sources of bias and errors when using an heterologous probing approach to analyse gene expression patterns are i) the efficiency of the hybridizations and ii) variations in gene family structure and gene sequence between species [35]. Therefore, it is important to validate results obtained with microarray, with an alternative approach such as RT-qPCR. The expression analyses of the pea $O M T$ and M. truncatula I7OMT gene illustrates these problems; Our microarray experiment showed that a gene similar to $M$. truncatula I7OMT was suppressed in response to $A$. euteiches at 20 hpi but the results obtained by RT-qPCR for a predicted pea $O$-methyltransferase (OMT) transcript with high similarity to $M$. truncatula I7OMT (75 \% amino acid identity), obtained from a pea RNA-seq assembly [8], showed induction of this gene at 20 hpi. Thus, the actual variation between the two I7OMT/ $O M T$ sequences, or potential variations in the $O M T$ gene family structure between the two species, interfered with the analysis. However the results of RT-qPCR for other target genes showed common expression pattern as in microarray, confirming the microarray analysis and indicating that the use of the M. truncatula microarray for studying the pea transcriptome is a reliable tool, as it was reported previously [14].

In the current work, we study compatible interactions between pea and the two pathogens $A$. euteiches and $P$. pisi, which results in disease. We hypothesise that in these compatible interactions the transcriptomic responses in pea are linked with immunity, and thus represent a failed defence response. However, there are examples of susceptibility genes in pea. The $P_{S} M L O 1$ gene, coding for a plant specific membrane protein with as yet unknown function, is an example of a susceptibility gene in pea against powdery mildew caused by Erysiphe pisi [36]. No susceptibility genes associated with $A$. euteiches or P. pisi are as yet identified in pea.

Comparison between time points for each pathogen and interspecies infection revealed distinct sets of differentially regulated genes in response to A. euteiches and $P$. pisi and at each time point. This indicates that the different pathogenicity mechanisms of $A$. euteiches or $P$. pisi lead to disparate transcriptional changes in pea. This interpretation is strengthened by the expression patterns of genes involved in pathogen perception and signalling where different sets of genes are specifically differentially regulated in response to each pathogen, indicating that different signalling molecules in pea are triggered by these two oomycetes.

Furthermore, the induction and suppression of genes associated with signal transduction pathways at $6 \mathrm{hpi}$ in response to both pathogens suggest that immunity responses associated with PTI or ETI occurs early in infection. Interestingly, many genes encoding NB-LRRs are suppressed early after infection, indicating that these oomycetes secrete and deliver their effectors into the pea root cells early during infection to suppress immune signalling leading to ETS. This idea is in line with the transcriptomic analysis of $P$. capsici-tomato interaction, 


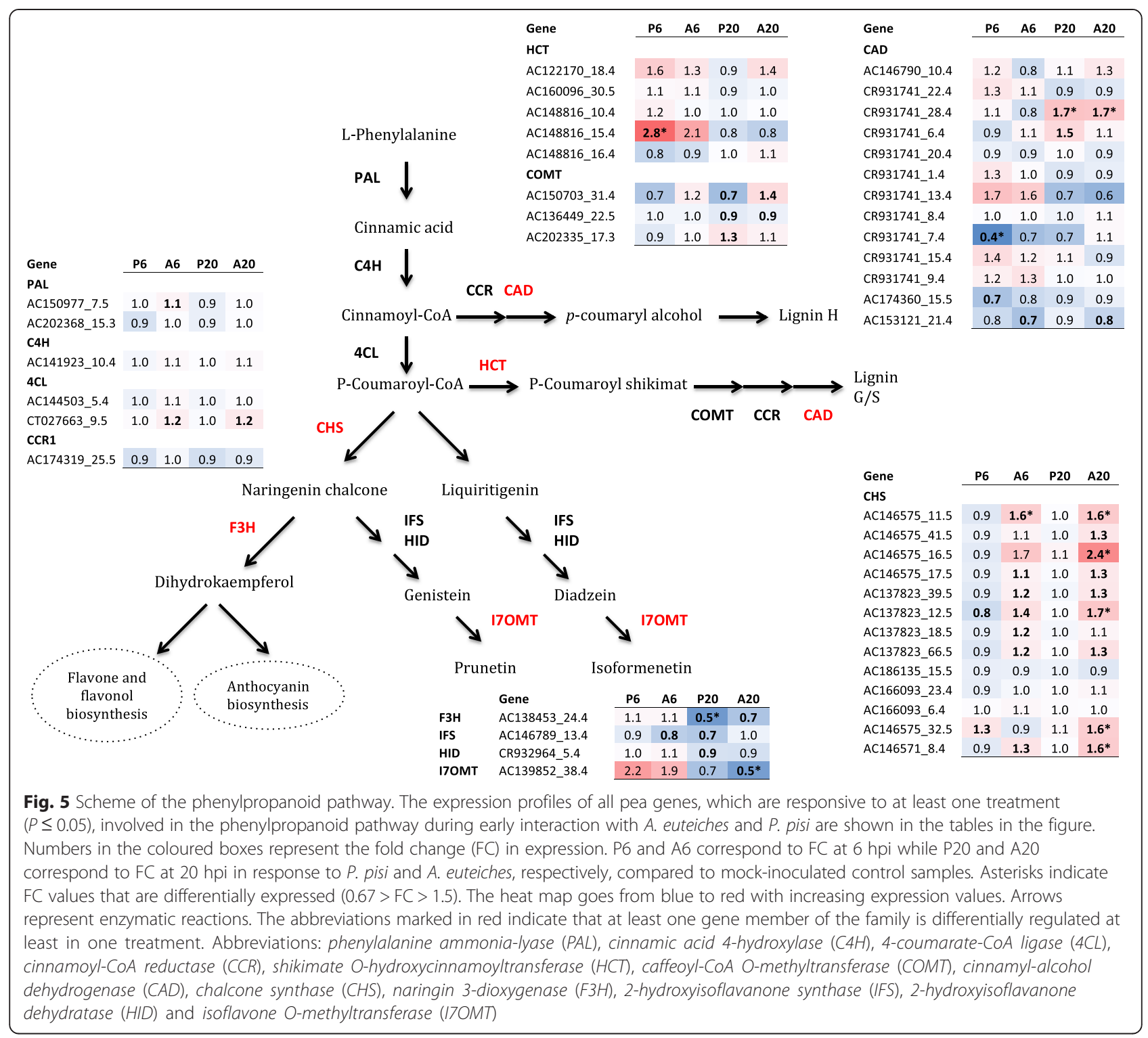

where a subset of pathogen effectors and host receptor genes were induced and repressed, respectively, during biotrophy [37]. Furthermore, the data indicates that some NB-LRR and LRR-RLK encoding genes in pea are triggered commonly against both pathogens while some are specifically activated at each time point responding to each of these oomycetes.

Transcriptional changes suggesting increased cell wall reinforcement are observed in response to both pathogens. Cell wall reinforcement contributes to the development of physical barriers through deposition of cell wall appositions at sites of pathogen detection as a common component of the PTI response [19, 38]. GSL genes of higher plants encode essential proteins for callose formation [39]. Therefore, induction of pea putative GSL genes early after infection against these oomycetes suggests the formation of callose at the infection site as a part of the defence mechanism. This is in agreement with a study where callose deposition was shown as a defence mechanism to restrict $P$. capsici growth at early time in an incompatible interaction with Arabidopsis thaliana [40]. Induction of a putative $C A D$ gene, involved in lignification, suggests that lignin deposition in the cell walls is part of the defence mechanism against both $A$. euteiches and $P$. pisi. This result is consistent with a study where lignin deposition in cell walls is shown to be a striking feature of M. truncatula partial resistance against $A$. euteiches [41].

Based on the expression pattern of the putative $L O X$ genes in response to $P$. pisi and A. euteiches, it appears that JA biosynthesis is down regulated at $6 \mathrm{hpi}$ and activated at 20 hpi. A crucial role of LOX compounds in resistance of tobacco in an incompatible interaction with 
Table 2 Expression of pea genes involved in cell wall modifications

\begin{tabular}{|c|c|c|c|c|c|}
\hline Description & $G e^{a}$ & P6hpi & A6hpi & P20hpi & $\overline{\text { A20hpi }}$ \\
\hline \multirow[t]{7}{*}{ Callose synthase } & AC137603_39.4 & 1.0 & $1.6^{\mathrm{b}}$ & 1.2 & 0.8 \\
\hline & AC155803_42.5 & 1.0 & 1.4 & 0.8 & 1.0 \\
\hline & AC155803_41.5 & $1.6^{\mathrm{b}}$ & 0.9 & 0.5 & $0.5^{\mathrm{b}}$ \\
\hline & AC155803_43.5 & 1.2 & 0.9 & 1.0 & 0.9 \\
\hline & AC122723_35.5 & 1.1 & 1.1 & 1.1 & 0.9 \\
\hline & CU012050_22.4 & 1.0 & 0.9 & 1.0 & 1.2 \\
\hline & AC202574_37.3 & 1.1 & 1.1 & 1.0 & 0.8 \\
\hline \multirow[t]{8}{*}{ Pectinesterase } & AC148775_45.5 & 0.9 & 0.8 & 1.0 & 1.0 \\
\hline & AC150204_16.5 & $0.6^{\mathrm{b}}$ & 0.8 & 0.9 & 1.0 \\
\hline & AC153005_36.5 & 1.0 & 1.2 & 0.9 & 1.1 \\
\hline & AC153005_9.5 & 0.9 & 0.7 & $0.3^{\mathrm{b}}$ & 0.7 \\
\hline & AC174141_27.4 & 1.3 & $1.5^{\mathrm{b}}$ & 1.1 & 1.1 \\
\hline & AC202348_3.4 & 1.0 & 1.1 & 1.0 & 1.3 \\
\hline & СТ009653_39.4 & 1.0 & 1.0 & 1.3 & $1.7^{\mathrm{b}}$ \\
\hline & AC152919_7.5 & 1.0 & 0.8 & $0.6^{\mathrm{b}}$ & 0.7 \\
\hline \multirow[t]{5}{*}{ Pectinesterase inhibitor } & AC122165_33.4 & 1.2 & 1.0 & $1.6^{\mathrm{b}}$ & 1.4 \\
\hline & AC160097_13.5 & 0.9 & 0.9 & 1.0 & 1.0 \\
\hline & AC160097_28.5 & 0.9 & 0.9 & 1.0 & 1.4 \\
\hline & AC165218_17.4 & 1.3 & 1.3 & 1.0 & 1.1 \\
\hline & AC173289_18.5 & 1.1 & 1.3 & 1.7 & $1.6^{\mathrm{b}}$ \\
\hline
\end{tabular}

${ }^{a}$ Refers to the gene accession numbers in $M$. truncatula A17 genome version 2 (Mt2.0)

Numbers indicate fold change (FC) ratios of expression levels of genes involved in hormonal signalling at 6 hpi and 20 hpi in response to $A$. euteiches and $P$. pisi compared with mock inoculation. A6hpi and P20hpi correspond to the expression values in response to A. euteiches at 6 hpi and 20 hpi, respectively, while P6hpi and P2Ohpi correspond to the expression values in response to $P$. pisi at $6 \mathrm{hpi}$ and $20 \mathrm{hpi}$, respectively. Bold values indicate if the treatment FC is significantly $(P \leq 0.05)$ different from the control. ${ }^{\mathbf{b}}$ Indicate if the FC expression levels are differentially expressed $(P \leq 0.05, \geq 1.5$ fold induction or $\leq 0.67$ fold repression)

P. parasitica was shown [42]. Furthermore, an increase in susceptibility of JA-deficient mutant tomato (Lycopersicon esculentum) plants to $P$. infestans has been reported [43]. Therefore, considering the role of JA as an important mediator in defence signalling against these oomycetes, we hypothesize that $P$. pisi and $A$. euteiches suppress JA biosynthesis in pea during the early phases of susceptible interactions for favouring the infection. Induction of JA pathway at $20 \mathrm{hpi}$ in pea is in agreement with a recent study on soybean - P. sojae interaction where the JA pathway was up regulated at 24 hpi in the susceptible soybean lines [44]. On the other hand, induction of $A C O$ genes that is positively correlated with ethylene production rates [45] suggests up regulation of ET biosynthesis pathway in pea upon infection with both pathogens. While ET and JA are often regarded to be part of the same signalling module, a negative regulatory relationship between components of these two pathways is reported [19]. Furthermore, nonsynergetic regulation of these two pathways is reported in compatible and incompatible soybean - P. sojae interactions at 24 hpi [44]. Activation of the ET pathway in response to $A$. euteiches is supported by induction of $E R F$, which is the transcription factor essential in ET signalling [46].

In contrast to the similarities in the regulation of JA and ET biosynthesis genes in pea during interactions with $P$. pisi and A. euteiches, induction of genes encoding auxin-induced SAUR family proteins appears to be specific to $A$. euteiches. The induction of SAUR family proteins may indicate an accumulation of auxin in roots during A. euteiches infection. Auxin signalling is reported to be important in $A$. thaliana resistance against oomycetes such as Pythium irregulare and Hyaloperonospora arabidopsidis $[47,48]$ and repression of this pathway enhances the susceptibility of $A$. thaliana to $P$. cinnamomi [49]. Recently, the polar auxin transport in roots was reported to be targeted by an RXLR effector of $P$. parasitica, the Penetration-Specific Effector 1 (PSE1), in compatible interactions with $A$. thaliana roots [50], leading to modulation of the auxin content (possibly by lowering the auxin concentrations) locally at the root apex to favour infection. A possible interpretation of our data is that P. pisi, but not A. euteiches, possess effectors that target and suppress 
Table 3 Expression of pea genes involved in hormonal signalling pathways

\begin{tabular}{|c|c|c|c|c|c|}
\hline Description & Gene $^{a}$ & P6hpi & A6hpi & P20hpi & A20hpi \\
\hline \multirow[t]{9}{*}{ Lipoxygenase (LOX) } & AY515253_32.4 & 1.0 & 0.8 & 1.2 & $1.5^{b}$ \\
\hline & AC146571_7.4 & 0.7 & 0.7 & $2.3^{\mathrm{b}}$ & 1.3 \\
\hline & AC140032_2.4 & 0.8 & 0.8 & $1.5^{\mathrm{b}}$ & 1.3 \\
\hline & AC149580_13.5 & $0.6^{\mathrm{b}}$ & $0.6^{\mathrm{b}}$ & 1.0 & 0.7 \\
\hline & AC149638_35.4 & 0.9 & 1.1 & 0.8 & 0.7 \\
\hline & AC149580_9.5 & 0.9 & 0.9 & 1.0 & 0.8 \\
\hline & AC149580_19.5 & 0.9 & 1.0 & 0.8 & 0.9 \\
\hline & AC140032_6.4 & 0.9 & 1.0 & 0.9 & 0.8 \\
\hline & AC140032_7.4 & 1.0 & 1.1 & 1.0 & 1.0 \\
\hline \multirow[t]{2}{*}{ Jasmonate O-methyltransferase } & AC152936_2.5 & 1.6 & 0.9 & 1.3 & $1.7^{\mathrm{b}}$ \\
\hline & CU024875_36.4 & 1.1 & 1.1 & 0.7 & 0.8 \\
\hline \multirow[t]{19}{*}{ Aminocyclopropane-carboxylate oxidase (ACO) } & AC146817_44.4 & 1.1 & 1.4 & 1.2 & 1.2 \\
\hline & AC174337_3.4 & 1.0 & 1.3 & 0.8 & 1.3 \\
\hline & AC169513_37.4 & $2.0^{\mathrm{b}}$ & $1.8^{\mathrm{b}}$ & 0.6 & 0.9 \\
\hline & AC125389_65.5 & $1.6^{\mathrm{b}}$ & 1.3 & 1.1 & 0.9 \\
\hline & AC119419_24.4 & 1.4 & 1.0 & 0.8 & 0.8 \\
\hline & AC158372_38.4 & 1.5 & 1.4 & $0.6^{\mathrm{b}}$ & 0.7 \\
\hline & AC146817_41.4 & 0.8 & 0.5 & $2.9^{b}$ & 2.1 \\
\hline & AC174337_15.4 & 1.2 & 0.9 & $2.0^{\mathrm{b}}$ & 1.4 \\
\hline & AC202309_24.3 & 1.3 & 1.1 & $1.5^{\mathrm{b}}$ & 0.7 \\
\hline & AC124966_44.4 & 1.3 & 1.2 & 0.9 & $1.8^{\mathrm{b}}$ \\
\hline & СТ025839_48.5 & 1.0 & $0.5^{\mathrm{b}}$ & 1.2 & 1.4 \\
\hline & CU013517_26.4 & 1.0 & 0.9 & 1.3 & 1.0 \\
\hline & AC197464_13.4 & 1.0 & 1.0 & 0.9 & 0.8 \\
\hline & AC158372_65.4 & 1.0 & 1.1 & 0.7 & $0.6^{\mathrm{b}}$ \\
\hline & AC169513_36.4 & 0.9 & 1.0 & 0.8 & 0.7 \\
\hline & AC158372_67.4 & 0.7 & 0.8 & 0.7 & 0.7 \\
\hline & AC158372_42.4 & 1.0 & 1.0 & 0.9 & 0.7 \\
\hline & AC169513_23.4 & 0.8 & 0.7 & 0.9 & 1.0 \\
\hline & AC169513_26.4 & 0.9 & 0.8 & 1.0 & 1.1 \\
\hline Ethylene-responsive transcription factor (ERF) & AC145767_15.4 & 1.0 & 1.0 & 1.3 & 1.6 \\
\hline Ethylene insensitive 3 (EIN3) & AC196764_17.3 & 0.9 & 0.9 & 1.0 & 1.3 \\
\hline \multirow[t]{12}{*}{ Auxin-induced protein (SAUR) } & CU326390_14.3 & 1.1 & 1.1 & 1.3 & $1.9^{\mathrm{b}}$ \\
\hline & AC149578_14.4 & 1.0 & 1.0 & 1.3 & 1.3 \\
\hline & AC148242_22.4 & 1.1 & 1.0 & 1.4 & 1.2 \\
\hline & AC148242_37.4 & 1.0 & 1.0 & 1.2 & 1.3 \\
\hline & AC148242_50.4 & 1.1 & 1.3 & 1.2 & $1.7^{\mathrm{b}}$ \\
\hline & AC148242_51.4 & 1.0 & 1.0 & 1.1 & 1.4 \\
\hline & AC146705_44.5 & 1.0 & 1.1 & 1.2 & 1.2 \\
\hline & AC146705_10.5 & 1.1 & 1.0 & 1.2 & 1.3 \\
\hline & AC146705_14.5 & 1.1 & 1.1 & 1.2 & 1.1 \\
\hline & AC146705_13.5 & 0.9 & 1.0 & 1.2 & $1.7^{\mathrm{b}}$ \\
\hline & AC146705_14.5 & 1.1 & 1.1 & 1.2 & 1.1 \\
\hline & CU024876_8.4 & 0.9 & 1.1 & 1.3 & 1.1 \\
\hline
\end{tabular}


Table 3 Expression of pea genes involved in hormonal signalling pathways (Continued)

\begin{tabular}{|c|c|c|c|c|c|}
\hline & CU024876_38.4 & 1.1 & 1.1 & 1.3 & 1.2 \\
\hline & AC146705_4.5 & 1.4 & 1.2 & 0.8 & 0.8 \\
\hline Auxin transporter-like protein 2-like & СТ030165_15.5 & 1.0 & 1.0 & 0.9 & 0.8 \\
\hline \multirow[t]{2}{*}{ Auxin-responsive protein } & CU459036_7.3 & 1.0 & 1.0 & 1.0 & 0.9 \\
\hline & AC152423_24.4 & 1.0 & 0.9 & 1.3 & 1.1 \\
\hline \multirow[t]{5}{*}{ Cullin-like protein1 } & AC150246_30.4 & 1.5 & 0.9 & 0.7 & 0.3 \\
\hline & CR931807_17.5 & $4.9^{\mathrm{b}}$ & 1.3 & 1.4 & 0.6 \\
\hline & CR956619_45.5 & $2.2^{\mathrm{b}}$ & 1.3 & 0.7 & 0.8 \\
\hline & CT573078_55.5 & $2.3^{b}$ & 1.7 & 0.3 & 0.5 \\
\hline & AC121235_22.5 & 1.7 & $2.1^{\mathrm{b}}$ & 1.2 & 1.3 \\
\hline Pathogenesis-related protein $1 \mathrm{~A}$ & AC150778_28.5 & 1.1 & 1.3 & 1.2 & $2.6^{b}$ \\
\hline Abscisic acid receptor PYL4-like & CT967319_16.4 & 1.0 & 1.0 & 1.0 & 1.1 \\
\hline Abscisic acid-insensitive 5-like protein 2-like & AC146910_18.5 & 1.2 & 1.2 & 0.9 & 1.1 \\
\hline Gibberellin receptor GID1c-like & AC188382_8.4 & 1.0 & 1.0 & 0.9 & 0.9 \\
\hline F-box family protein & AC146792_3.5 & 0.9 & 1.0 & 1.0 & 0.8 \\
\hline Transcription factor HBP-1b -like & AC157891_47.4 & 1.0 & 1.0 & 0.9 & 0.9 \\
\hline Two-component response regulator ARR9-like & AC153125_5.5 & 0.7 & $0.4^{b}$ & $0.5^{\mathrm{b}}$ & $0.5^{\mathrm{b}}$ \\
\hline TGACG-sequence-specific DNA-binding protein & AC202316_14.3 & 0.9 & 0.9 & 0.8 & 0.9 \\
\hline BTB/POZ ankyrin repeat protein & AC147961_14.5 & 0.9 & 1.0 & 0.9 & 0.9 \\
\hline Protein phosphatase 2 C 37 -like & CR954191_11.4 & 0.9 & 0.9 & 0.9 & 1.0 \\
\hline Acyl-CoA oxidase & CT573502_1.5 & 1.1 & 1.1 & 1.1 & 1.2 \\
\hline
\end{tabular}

${ }^{\mathrm{a}}$ Refers to the gene accession numbers in $M$. truncatula A17 genome version 2 (Mt2.0)

Numbers indicate fold change (FC) ratios of expression levels of genes involved in hormonal signalling at 6 hpi and 20 hpi in response to $A$. euteiches and $P$. pisi compared with mock inoculation. A6hpi and A20hpi correspond to the expression values in response to A. euteiches at 6 hpi and 20 hpi, respectively, while P6hpi and $\mathrm{P} 20 \mathrm{hpi}$ correspond to the expression values in response to $P$. pisi at $6 \mathrm{hpi}$ and $20 \mathrm{hpi}$, respectively. Bold values indicate if the treatment FC is significantly $(P \leq 0.05)$ different from the control. ${ }^{\mathbf{b}}$ Indicate if the FC expression levels are differentially expressed $(P \leq 0.05, \geq 1.5$ fold induction or $\leq 0.67$ fold repression)

auxin accumulation in pea roots, thereby favouring infection.

Induction of $C H S$ genes putatively encoding chalcone synthases also appears to be specific to infection by $A$. euteiches. Naringenin chalcone that is the product of the CHS reaction, is a substrate for the production of a wide range of secondary metabolites, including flavones, isoflavonoid phytoalexins, and anthocyanins. Legumes utilize flavonoid compounds, notably isoflavones and isoflavanones in defence against pathogens and as signalling molecules [22]. Induction of genes in the phenylpropanoid pathway, such as phenylalanine ammonia-lyase (PAL), $C H S$ and isoflavone synthase, was shown to be rapid and strong in compatible interaction in soybean against $P$. sojae [51]. Furthermore, induction of genes involved in this pathway was reported in M. truncatula in response to pathogen infection such as Erysiphe pisi and Colletotrichum trifolii [52-54]. Taken together, the induction of CHS genes during infection by $A$. euteiches suggests that biosynthesis of secondary metabolites e.g. isoflavonoid phytoalexins, is a part of plant immunity response to this pathogen.
Local resistance of pea root tips against A. euteiches is previously reported to be associated with an increase in pisatin production in the border cells [4], and silencing of HMM6 results in reduced pisatin production [55]. Induction of pea HMM6 in response to A. euteiches suggests that pisatin synthesis might be part of the defence response against this pathogen.

\section{Conclusions}

Our results show that different gene sets are triggered in pea by $A$. euteiches and $P$. pisi, leading to distinct and common transcriptional responses during the early phase of susceptible interaction with these two distantly related oomycetes. Cell wall reinforcement and modulation of JA and ET pathways are similar in response to both pathogens, while induction of the auxin pathway and chalcone synthesis is specific response to A. euteiches (Fig. 7). Taken together, this knowledge will lead to a better understanding of the early defence response in pea against these important pathogens. Future advances in our understanding of oomycete infection mechanisms will explain more of the distinct patterns we observe. 


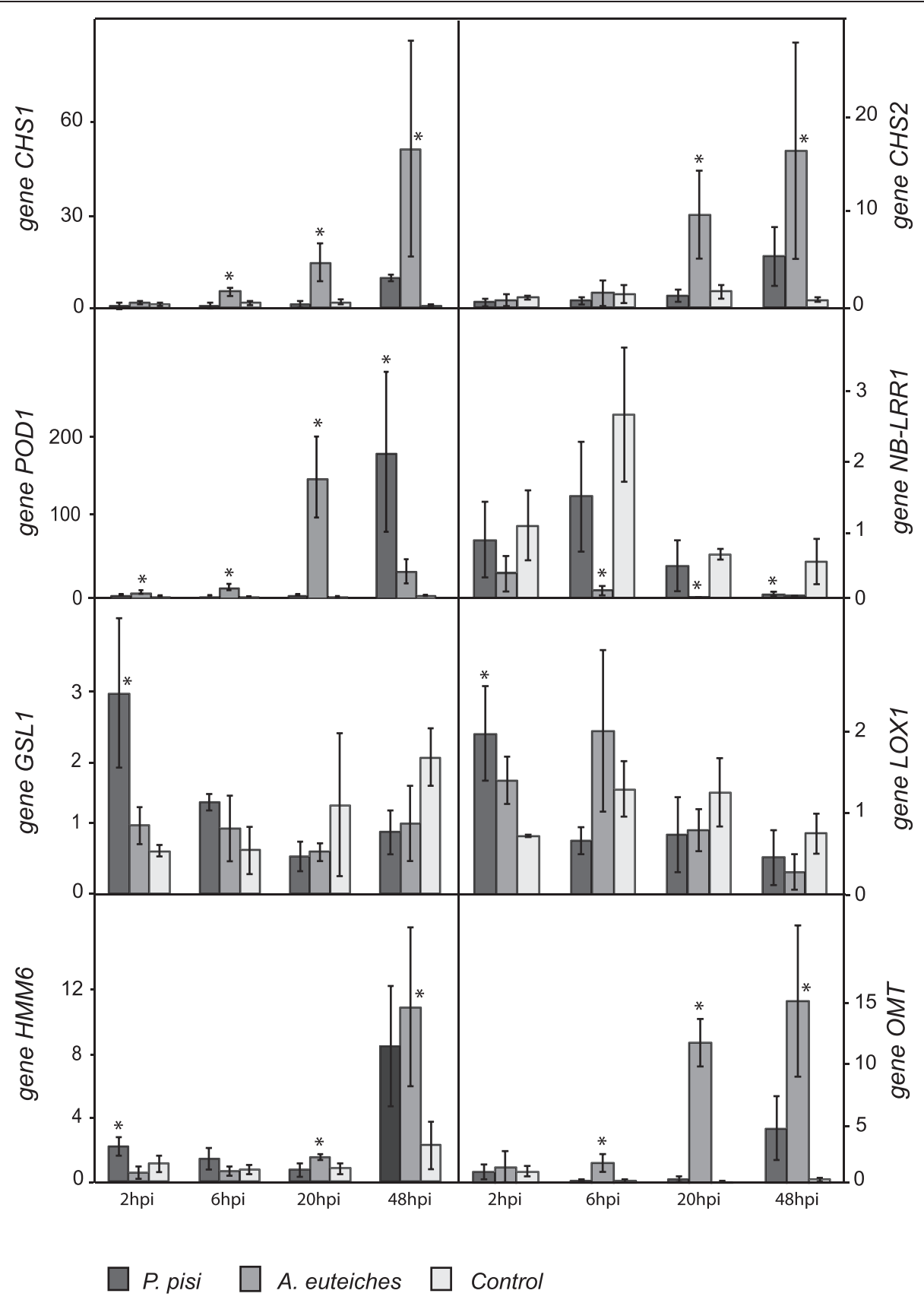

Fig. 6 Expression profiles of selected pea genes during interaction with A. euteiches and $P$. pisi. Relative expression levels were normalized by $\beta$-tubulin (TUB) expression, and presented in relation to control pea plants at 2 hpi (= expression level 1) using the $2^{-\Delta \Delta c t}$ formula. Error bars represent standard deviation based on at least 4 biological replicates. Asterisks indicate statistically significant $(P \leq 0.05)$ differences between infection treatments and control plants within time points according to the Fisher test. Abbreviations: chalcone synthesis (CHS1, CHS2), peroxidase (POD1), nucleotide binding - leucine rich repeat resistance (NB-LRR1), callose synthase (GSL1), lipoxygenase (LOX1), 6a-hydroxymaackiain methyltransferase (HMM6) and O-methyltransferase (OMT)

\section{Methods}

\section{Plant material and inoculation}

Pea seeds, cv. "Finulf", were surface sterilized in sodium hypochlorite $(10 \% v / v)$ for $3 \mathrm{~min}$, and washed in water. The seeds were then germinated in moist autoclaved paper towels by incubation in darkness at $25{ }^{\circ} \mathrm{C}$ for four days. Strain 97603 of $P$. pisi and strain $11 \mathrm{k} 3$ of $A$. euteiches were grown on dilute vegetable Granini Juice agar (4\% filtered juice and $2 \%$ Bacto Agar) at $25{ }^{\circ} \mathrm{C}$. Zoospores of these two species were produced as described previously [29]. The concentration of zoospores was further determined with a haemocytometer and 


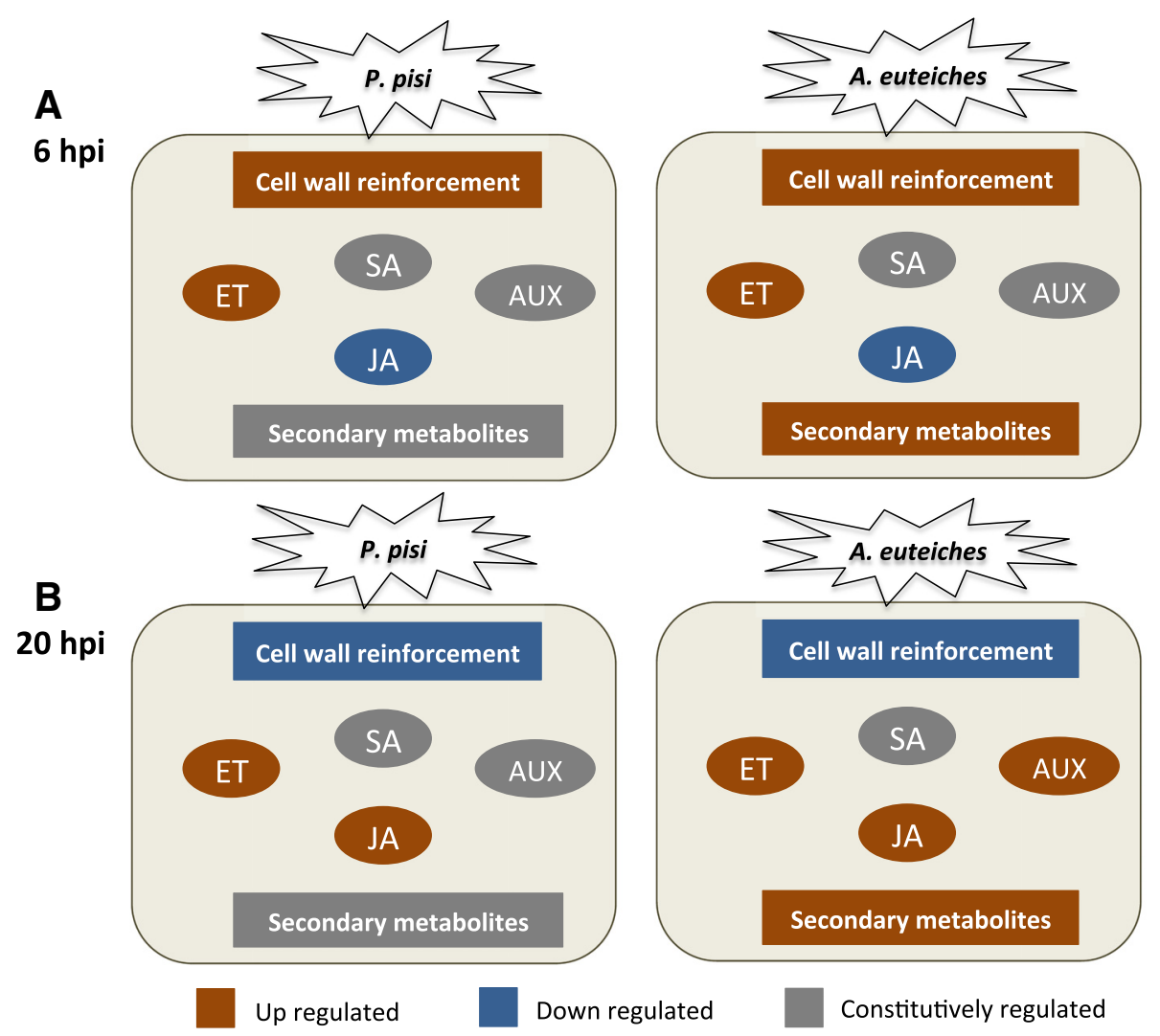

Fig. 7 Differentially regulated defense sectors in pea. Summary of defense-related transcriptional differences in pea during compatible interactions with Aphanomyces euteiches and Phytophthora pisi at 6 hpi (a) and 20 hpi (b). Abbreviations: Ethylene pathway (ET), Salicylic acid pathway (SA), Auxin pathway (AUX), Jasmonic acid pathway (JA)

adjusted to $10^{5}$ zoospores per ml. Germinated pea seedlings with approximately $4 \mathrm{~cm}$ roots were selected and the roots were incubated in the zoospore suspension of each species for $30 \mathrm{~min}$ in a previously described infection system [29], followed by incubation in a growth chamber with $16 \mathrm{~h}$ light at $22{ }^{\circ} \mathrm{C}$ and high humidity. Roots were harvested at $0,30 \mathrm{~min}, 1,2,6,20$ and 48 hpi. At each time point, mock-inoculated control plants grown under the same conditions were harvested. Each treatment was performed in three replicates, each consisting of 10 pea roots. For nucleic acid extractions, the distal ends of the pea roots were cut about $1 \mathrm{~cm}$ from the tips, ground in liquid $\mathrm{N}_{2}$ and stored at $-80{ }^{\circ} \mathrm{C}$.

\section{Nucleic acid isolation and DNase I treatment}

Total RNA was extracted using a phenol-chloroform protocol as described by Dubey et al. [56], followed by $\mathrm{NaOAc} /$ ethanol purification and proceeded to the RNeasy Plant Mini Kit (Qiagen, Hilden, Germany) according to the manufacturer's instructions. Traces of DNA were removed by DNase I treatment (Fermentas). RNA concentration was determined spectrophotometrically using Nano-Drop (Thermo Scientific), and RNA quality was assessed after electrophoresis on an Agilent Bioanalyzer using the RNA 6000 nano kit (Agilent Technologies, Santa Clara, CA) according to the manufacturer's instructions. DNase I treated RNA was further diluted to $1-2 \mu \mathrm{g} / \mu \mathrm{l}$ for microarray analysis.

\section{Microarray experiment and analysis}

Samples taken at 6 and 20 hpi were selected for the microarray experiment. The microarray hybridizations were performed at Swegene center for integrative biology at Lund University, Sweden. $200 \mathrm{ng}$ of DNAse I treated samples were used for cDNA synthesis and labeling by Biotin Allonamide Triphosphate at $37{ }^{\circ} \mathrm{C}$. The Medicago MedGene-1-0-st array, designed based on the M. truncatula A17 genome version 2 (Mt2.0), was used for this experiment. The experiment included three biological and two technical replicates incorporating one dye swap.

Basic Affymetrix chip and Experimental Quality Analyses were performed using the Expression Console Software V1.1.2. Probe summarization and data normalization method, Robust Multi-array Analysis (RMA) was done as 
described by Irizarry et al. [57]. Signals were $\log _{2}$ transformed. To identify differentially expressed genes in inoculated samples at each time point compared to control samples, the Limma model [25] in the R software was used [58]. Genes that were statistically differently regulated at each time point compared to the corresponding control samples $(P \leq 0.05)$, were considered as responsive genes to that time point. Among these genes, those with $\log _{2}$ expression ratio treatment/control $\geq 0.584$ ( $>1.5$ fold induction or $\leq 0.67$ repression) were regarded as differentially expressed genes. Venn diagrams of differentially expressed gene sets were generated using Venny [59]. Hierarchical clustering of all genes that were differentially expressed at least in one condition was performed using the HCE3.5 software [60] with the complete linkage method and the Manhattan measure. Hierarchical clustering of $R$ genes was generated in R software. Blast2GO [61] analysis was performed to provide Gene Ontology annotation according to BlastP [62] hits against the NCBI with an e-value threshold of 1e-6. Functional category assignment for differentially expressed genes was conducted using the WEGO online server [63], classifying according to GO terms within molecular functions, biological processes and cellular components. KEGG Automatic Annotation Server (KAAS) Ver. 1.69x [64] was used to annotate protein sequences using orthologs of plant enzymes $(A$. thaliana and G. max) to obtain KEGG Orthology (KO) and Enzyme Commission (EC) numbers. The enzyme EC codes were mapped to the KEGG database [65] using the KEGG mapper-reconstruct pathways tool (Ver. 2.0) [66]. Domain structure and family of possible resistance genes were investigated using the InterPro online server [67]. Microarray data have been deposited in ArrayExpress (http://www.ebi.ac.uk/arrayexpress/) under accession number E-MTAB-3748.

\section{Assessment of gene expression using RT-qPCR}

For validation of microarray data, eight $P$. sativum genes with similarity ( $\geq 70 \%$ amino acid identity) to $M$. truncatula genes previously reported to be involved in defence were retrieved from NCBI or pea transcriptome data [8]. Primers used for RT-qPCR were designed towards sequences of pea genes to amplify amplicons ranging from 80 to 200 bp using Primer Select software (Dnastar, Madison, WI) (Additional file 8).

Reverse transcription of $1 \mu \mathrm{g}$ of the same DNase I treated RNA used for microarray analysis was carried out in a $20 \mu \mathrm{l}$ reaction volume using the iScript cDNA Synthesis Kit (Bio-Rad, Hercules, CA) according to the manufacturer's instructions. The synthesized cDNA was diluted $10 \times$ into a final volume of $200 \mu \mathrm{l}$. Transcript levels were quantified using an iQ5 qPCR System (Bio-Rad, Hercules, CA). Each $20 \mu \mathrm{l}$ reaction contained $5 \mu \mathrm{l}$ of diluted cDNA, $150 \mathrm{nM}$ of each primer and $10 \mu \mathrm{l}$ SsoFast
EvaGreen Supermix (Bio-Rad, Hercules, CA). The following PCR protocol was used: $98^{\circ} \mathrm{C}$ for $2 \mathrm{~min}, 40$ cycles of $98{ }^{\circ} \mathrm{C}$ for $5 \mathrm{~s}, 60^{\circ} \mathrm{C}$ for $10 \mathrm{~s}$ and $72^{\circ} \mathrm{C}$ for $10 \mathrm{~s}$. Amplification of a single product was confirmed by melt curve analysis, while primer amplification efficiency was deducted from amplification of standard curves using dilution series of genomic DNA.

Relative expression values for $P$. sativum target genes were calculated from the Ct values according to the $2^{-\Delta \Delta \mathrm{Ct}}$ method [68], and normalised by the elongation factor alfa (EFA) [29] or $\beta$-tubulin (TUB) [69] reference genes. Transcript levels were determined in 4 biological replicates, each based on 2 technical replicates. Analysis of variance (ANOVA) was conducted using a General Linear Model implemented in SPSS ver. 21 (IBM, Armonk, NY) or Statistica ver. 12 (StatSoft Inc., Tulsa, OK). Pairwise comparisons were made using Fisher's method at the $95 \%$ significance level.

\section{Availability of supporting data}

The data supporting the results of this article are included within the article and its additional files.

\section{Additional files}

\begin{abstract}
Additional file 1: Figure S1. Expression profiles of selected marker pea genes during interaction with $A$. euteiches and $P$. pisi. Expression patterns of four pea genes in response to both pathogens were investigated by RT-qPCR. Relative expression levels were normalized by elongation factor alfa (EFA) expression, and presented in relation to $P$. pisi-infected plants at $1 \mathrm{hpi}$ (= expression level 1 ) using the $2^{-\Delta \Delta \mathrm{Ct}}$ formula. Error bars represent standard deviation based on three biological replicates. Asterisks indicate statistically significant $(P \leq 0.05)$ differences between infection treatments and control plants at $48 \mathrm{hpi}$ according to the Fisher test. (PDF $427 \mathrm{~kb}$ )
\end{abstract}

Additional file 2: Table S1. List of all pea responsive genes to infection with $A$. euteiches. Microsoft Excel spreadsheet containing complete list of pea responsive genes to A. euteiches infection at 6 hpi (A6UP, A6DOWN) and 20 hpi (A20UP, A20DOWN). All genes have $P \leq 0.05$ on $\log _{2}$ of fold change (FC) expression levels compared to the control samples. Each gene is presented by the $M$. truncatula gene ID (column A), annotation (column B), minimum E-value (the lowest E-value of the ten best hits) (column C), mean similarity (the average similarity value of the ten best hits) (column D) and enzyme code (column E) provided by Blast2GO. Ratios of $\log _{2}$ on the FC between each treatment and the corresponding control samples are presented in column F. Differentially expressed genes $(P \leq 0.05, \geq 1.5$ fold induction or $\leq 0.67$ fold repression) are marked with light blue colour. (XLSX $465 \mathrm{~kb}$ )

Additional file 3: Table S2. List of all pea responsive genes to infection with P. pisi. Microsoft Excel spreadsheet containing complete list of list of pea responsive genes to $P$. pisi infection at 6 hpi (P6UP, P6DOWN) and 20 hpi (P20UP, P20DOWN). All the genes have $P \leq 0.05$ on $\log _{2}$ of fold change $(\mathrm{FC})$ expression levels to the control samples. Each gene is presented by the M. truncatula gene ID (column A), annotation (column B), minimum E-value (the lowest E-value of the ten best hits) (column C), mean similarity (the average similarity value of the ten best hits) (column D) and enzyme code (column E) provided by Blast2GO. Ratios of $\log _{2}$ on the FC between each treatment and the corresponded control samples are presented in column F. Differentially expressed genes $(P \leq 0.05, \geq 1.5$ fold induction or $\leq 0.67$ fold repression) are marked with light blue colour. (XLSX $329 \mathrm{~kb}$ ) 
Additional file 4: Figure S2. GO classification of differentially expressed pea genes in response to $A$. euteiches and P. pisi. Up regulated and down regulated genes ( $P \leq 0.05, \geq 1.5$ fold induction or $\leq 0.67$ fold repression) in response to A. euteiches at $6 \mathrm{hpi}(\mathrm{A})$ and $20 \mathrm{hpi}(\mathrm{B})$, to P. pisi at $6 \mathrm{hpi}$ (C) and $20 \mathrm{hpi}$ (D). The plots were generated using WEGO. (PDF $2895 \mathrm{~kb}$ )

Additional file 5: Table S3. List of differentially expressed pea genes during interaction with A. euteiches and P. pisi. Microsoft Excel spreadsheet containing $M$. truncatula gene IDs (column A), annotation (column B), minimum E-value (the lowest E-value of the ten best hits, column C), mean similarity (the average similarity value of the ten best hits, column E) and enzyme code (column E) provided by Blast2GO. Ratio of the $\log _{2}$ expression between each treatment and the corresponded control samples is presented in column F to I. Genes are clustered based on their expression patterns as shown in Fig. 2. Sheets 2 and 3 represent the genes in sub-clusters $1 \mathrm{~b}$ and $2 \mathrm{a}$, respectively, which are mainly induced in response to both pathogens at 6 hpi. Sheets 1 and 4 represent the genes in sub-clusters $1 \mathrm{a}$ and $2 \mathrm{~b}$ that are specifically induced in response to P. pisi and A. euteiches at 6 hpi, respectively. Sheets 6 and 7 represent the genes in sub-clusters $3 b$ and $4 a$, respectively, which are induced in response to both pathogens at 20 hpi. Sheets 5 and 8 represent the genes in sub-clusters $3 a$ and $4 b$ that are specifically induced at $20 \mathrm{hpi}$ in response to $A$. euteiches and P. pisi, respectively. (XLSX $280 \mathrm{~kb}$ )

Additional file 6: Figure S3. Gene ontologies $(\mathrm{GO})$ enriched in the early defence transcriptional response in pea. Percentage of genes with significantly enriched $(P<0.005) \mathrm{GO}$ terms that were identified in cluster 1 and 2 (representing genes induced at $6 \mathrm{hpi}$ in response to both pathogens), compared with the background (genes induced at $20 \mathrm{hpi}$, present in cluster 3 and 4). (PDF $347 \mathrm{~kb}$ )

Additional file 7: Table S4. List of differentially expressed pea genes involved in signalling during interaction with $A$. euteiches and P. pisi. Microsoft Excel spreadsheet containing M. truncatula gene IDs (column A), annotation (column B), minimum E-value (the lowest E-value of the ten best hits, column C), mean similarity (the average similarity value of the ten best hits, column E) and enzyme code (column E) provided by Blast2GO. Ratio of the $\log _{2}$ expression between each treatment and the corresponded control samples is presented in column $\mathrm{F}$ to I. Genes are clustered based on their expression patterns as shown in Fig. 3a. Sheet 5 represents all the possible resistance genes involved in signalling pathways with the gene ID (column A), heat map of ratio of the $\log _{2}$ expression patterns (column B to E), annotation (column F) and domain structure and family generated by InterPro (column G). (XLSX $71 \mathrm{~kb}$ )

Additional file 8: Table S5. Primers used in this study for RT-qPCR analysis. (DOCX $20 \mathrm{~kb}$ )

\section{Abbreviations}

ABA: Abscisic acid; ACO: 1-aminocyclopropane-1-carboxylate oxidase; ANOVA: Analysis of variance; CAD: Cinnamyl-alcohol dehydrogenase; Chit: Chitinase; CHS: Chalcone synthases; EC: Enzyme Commission; EFA: Elongation factor alfa; ERF: Ethylene-responsive transcription factor; ET: Ethylene; ETI: Effector-triggered immunity; ETS: Effector-triggered susceptibility; GO: Gene Ontology; GSL: Callose synthases; HCT: Shikimate O-hydroxycinnamoyltransferase; HMM6: 6a-hydroxymaackiain methyltransferase; I7OMT: Isoflavone 7-O-methyltransferase; JA: Jasmonic acid; KEGG: Kyoto Encyclopedia of Genes and Genomes database; KO: KEGG Orthology; LOX: Lipoxygenase; LRR: Leucine-rich repeat protein; MAMPs: Microbe-associated molecular patterns; NB: Nucleotide binding domain; OMT: O-methyltransferase; PAL: Phenylalanine ammonia-lyase; PAMPs: Pathogen-associated molecular patterns; POD: Peroxidase; PTI: Pattern-triggered immunity; RLK: Receptor-like kinases genes; SA: Salicylic acid; TUB: $\beta$-tubulin

\section{Competing interests}

The authors declare that they have no competing interests.

\section{Authors' contributions}

SH contributed to the experimental design of the study, performed experiments and bioinformatics analysis, and drafted the manuscript. ME contributed to the experimental design of the study, provided guidance with the analysis, participated in bioinformatics analysis and drafted the manuscript. FH contributed to the experimental design of the projects and performed experiments. DFJ contributed to the experimental design of the study and supervision. MK conceived of the study, contributed to the experimental design of the study and analysed data, drafted the manuscript and supervised the work. All authors contributed to writing the manuscript. All authors read and approved the final manuscript.

\section{Acknowledgement}

This work was funded by the Nilsson-Ehle donations and the Department of Forest Mycology and Plant Pathology at the Swedish University of Agricultural Sciences.

Received: 20 January 2015 Accepted: 7 August 2015 Published online: 21 August 2015

\section{References}

1. Sugiyama A, Yazaki K. Root exudates of legume plants and their involvement in interactions with soil microbes. In: Vivanco J, Baluska F. editors. Secretions and Exudates in Biological Systems, vol. 12. Berlin Heidelberg: Springer; 2012. p. 27-48.

2. Jones FR, Drechsler C. Root rot of peas in the United States caused by Aphanomyces euteiches (n. sp.). J Agric Res. 1925;30(4):293-325.

3. Gaulin E, Jacquet C, Bottin A, Dumas B. Root rot disease of legumes caused by Aphanomyces euteiches. Mol Plant Pathol. 2007;8(5):539-48.

4. Cannesan MA, Gangneux C, Lanoue A, Giron D, Laval K, Hawes M, et al. Association between border cell responses and localized root infection by pathogenic Aphanomyces euteiches. Ann Bot. 2011;108(3):459-69.

5. Grau CR, Muehlchen AM, Tofte JE, Smith RR. Variability in virulence of Aphanomyces euteiches. Plant Dis. 1991;75(11):1153-6.

6. Wicker E, Moussart A, Duparque M, Rouxel F. Further contributions to the development of a differential set of pea cultivars (Pisum sativum) to investigate the virulence of isolates of Aphanomyces euteiches. Eur J Plant Pathol. 2003;109(1):47-60.

7. Heyman F, Blair JE, Persson L, Wikstrom M. Root rot of pea and faba bean in southern Sweden caused by Phytophthora pisi sp nov. Plant Dis. 2013;97(4):461-71.

8. Franssen SU, Shrestha RP, Brautigam A, Bornberg-Bauer E, Weber APM. Comprehensive transcriptome analysis of the highly complex Pisum sativum genome using next generation sequencing. BMC Genomics. 2011;12:227.

9. Gao LL, Klingler JP, Anderson JP, Edwards OR, Singh KB. Characterization of pea aphid resistance in Medicago truncatula. Plant Physiol. 2008;146(3):996-1009.

10. Moussart A, Onfroy C, Lesne A, Esquibet M, Grenier E, Tivoli B. Host status and reaction of Medicago truncatula accessions to infection by three major pathogens of pea (Pisum sativum) and alfalfa (Medicago sativa). Eur J Plant Pathol. 2007;117(1):57-69.

11. Pilet-Nayel ML, Prosperi JM, Hamon C, Lesne A, Lecointe R, Le Goff I, et al. AER1, a major gene conferring resistance to Aphanomyces euteiches in Medicago truncatula. Phytopathology. 2009;99(2):203-8.

12. Choi HK, Mun JH, Kim DJ, Zhu H, Baek JM, Mudge J, et al. Estimating genome conservation between crop and model legume species. Proc Natl Acad Sci U S A. 2004;101(43):15289-94.

13. Kalo P, Seres A, Taylor SA, Jakab J, Kevei Z, Kereszt A, et al. Comparative mapping between Medicago sativa and Pisum sativum. Mol Genet Genomics. 2004;272(3):235-46.

14. Fondevilla S, Kuster H, Krajinski F, Cubero Jl, Rubiales D. Identification of genes differentially expressed in a resistant reaction to Mycosphaerella pinodes in pea using microarray technology. BMC Genomics. 2011;12:28.

15. Zipfel C. Early molecular events in PAMP-triggered immunity. Curr Opin Plant Biol. 2009;12(4):414-20.

16. Chisholm ST, Coaker G, Day B, Staskawicz BJ. Host-microbe interactions: shaping the evolution of the plant immune response. Cell. 2006;124(4):803-14.

17. Jones JD, Dangl JL. The plant immune system. Nature. 2006;444(7117):323-9.

18. Miljkovic D, Stare T, Mozetic I, Podpecan V, Petek M, Witek K, et al. Signalling network construction for modelling plant defence response. PLoS One. 2012;7(12):e51822.

19. Sato M, Tsuda K, Wang L, Coller J, Watanabe Y, Glazebrook J, et al. Network modeling reveals prevalent negative regulatory relationships between 
signaling sectors in Arabidopsis immune signaling. PLoS Pathog. 2010;6(7):e1001011.

20. He XZ, Dixon RA. Genetic manipulation of isoflavone 7-0-methyltransferase enhances biosynthesis of 4'-O-methylated isoflavonoid phytoalexins and disease resistance in alfalfa. Plant Cell. 2000;12(9):1689-702.

21. O'Neill NR, Saunders JA. Compatible and incompatible responses in alfalfa cotyledons to races 1 and 2 of Colletotrichum trifolii. Phytopathology. 1994;84(3):283-7.

22. Dixon RA, Achnine L, Kota P, Liu CJ, Reddy MS, Wang L. The phenylpropanoid pathway and plant defence-a genomics perspective. Mol Plant Pathol. 2002;3(5):371-90.

23. Kamoun S. Nonhost resistance to Phytophthora: novel prospects for a classical problem. Curr Opin Plant Biol. 2001;4(4):295-300.

24. Gaulin E, Madoui MA, Bottin A, Jacquet C, Mathe C, Couloux A, et al. Transcriptome of Aphanomyces euteiches: new oomycete putative pathogenicity factors and metabolic pathways. PLoS One. 2008;3(3):e1723.

25. Smyth GK. Limma: linear models for microarray data. In: Gentleman R, Carey V, Dudoit S, Irizarry R, Huber W, editors. Bioinformatics and Computational Biology Solutions using R and Bioconductor. New York: Springer; 2005. p. 397-420.

26. Zhang Z, Zhang H, Quan R, Wang XC, Huang R. Transcriptional regulation of the ethylene response factor LeERF2 in the expression of ethylene biosynthesis genes controls ethylene production in tomato and tobacco. Plant Physiol. 2009;150(1):365-77.

27. McClure BA, Guilfoyle T. Characterization of a class of small auxin-inducible soybean polyadenylated RNAs. Plant Mol Biol. 1987;9(6):611-23.

28. Markakis MN, Boron AK, Van Loock B, Saini K, Cirera S, Verbelen JP, et al. Characterization of a small auxin-up RNA (SAUR)-like gene involved in Arabidopsis thaliana development. PLoS One. 2013:8(11):e82596.

29. Hosseini S, Karlsson M, Jensen DF, Heyman F. Quantification of Phytophthora pisi DNA and RNA transcripts during in planta infection of pea. Eur J Plant Pathol. 2012;132(3):455-68

30. Colditz F, Nyamsuren O, Niehaus K, Eubel H, Braun HP, Krajinski F. Proteomic approach: identification of Medicago truncatula proteins induced in roots after infection with the pathogenic oomycete Aphanomyces euteiches. Plant Mol Biol. 2004;55(1):109-20.

31. Salzer P, Bonanomi A, Beyer K, Vogeli-Lange R, Aeschbacher RA, Lange J, et al. Differential expression of eight chitinase genes in Medicago truncatula roots during mycorrhiza formation, nodulation, and pathogen infection. Mol Plant Microbe Interact. 2000;13(7):763-77.

32. Young ND, Debelle F, Oldroyd GE, Geurts R, Cannon SB, Udvardi MK, et al. The Medicago genome provides insight into the evolution of rhizobial symbioses. Nature. 2011;480(7378):520-4.

33. Schmutz J, Cannon SB, Schlueter J, Ma J, Mitros T, Nelson W, et al. Genome sequence of the palaeopolyploid soybean. Nature. 2010;463(7278):178-83.

34. Schmutz J, McClean PE, Mamidi S, Wu GA, Cannon SB, Grimwood J, et al. A reference genome for common bean and genome-wide analysis of dual domestications. Nature Genet. 2014;46(7):707-13

35. Buckley BA. Comparative environmental genomics in non-model species: using heterologous hybridization to DNA-based microarrays. J Exp Biol. 2007;210(Pt 9):1602-6.

36. Humphry M, Reinstädler A, Ivanov S, Bisseling T, Panstruga R. Durable broad-spectum powdery mildew resistance in pea er 1 plants is conferred by natural loss-of-funtion mutations in PSMLO1. Mol Plant Pathol. 2011;12(9):866-78.

37. Jupe J, Stam R, Howden AJ, Morris JA, Zhang R, Hedley PE, et al. Phytophthora capsici-tomato interaction features dramatic shifts in gene expression associated with a hemi-biotrophic lifestyle. Genome Biol. 2013;14(6):R63.

38. Nicaise V, Roux M, Zipfel C. Recent advances in PAMP-triggered immunity against bacteria: pattern recognition receptors watch over and raise the alarm. Plant Physiol. 2009;150(4):1638-47.

39. Jacobs AK, Lipka V, Burton RA, Panstruga R, Strizhov N, Schulze-Lefert P, et al. An Arabidopsis callose synthase, GSL5, is required for wound and papillary callose formation. Plant Cell. 2003;15(11):2503-13.

40. Wang Y, Bouwmeester K, van de Mortel JE, Shan W, Govers F. A novel Arabidopsis-oomycete pathosystem: differential interactions with Phytophthora capsici reveal a role for camalexin, indole glucosinolates and salicylic acid in defence. Plant Cell Environ. 2013;36(6):1192-203.

41. Djebali N, Jauneau A, Ameline-Torregrosa C, Chardon F, Jaulneau V, Mathe $C$, et al. Partial resistance of Medicago truncatula to Aphanomyces euteiches is associated with protection of the root stele and is controlled by a major QTL rich in proteasome-related genes. Mol Plant Microbe Interact. 2009;22(9):1043-55.

42. Rance I, Fournier J, Esquerre-Tugaye MT. The incompatible interaction between Phytophthora parasitica var. nicotianae race 0 and tobacco is suppressed in transgenic plants expressing antisense lipoxygenase sequences. Proc Natl Acad Sci U S A. 1998;95(11):6554-9.

43. Thaler JS, Owen B, Higgins VJ. The role of the jasmonate response in plant susceptibility to diverse pathogens with a range of lifestyles. Plant Physiol. 2004;135(1):530-8.

44. Lin F, Zhao M, Baumann DD, Ping J, Sun L, Liu Y, et al. Molecular response to the pathogen Phytophthora sojae among ten soybean near isogenic lines revealed by comparative transcriptomics. BMC Genomics. 2014;15:18.

45. Rudus I, Sasiak M, Kepczynski J. Regulation of ethylene biosynthesis at the level of 1-aminocyclopropane-1-carboxylate oxidase (ACO) gene. Acta Physiol Plant. 2013;35(2):295-307.

46. Wang KL, Li H, Ecker JR. Ethylene biosynthesis and signaling networks. Plant Cell. 2002;14(Suppl):131-51.

47. Tiryaki I, Staswick PE. An Arabidopsis mutant defective in jasmonate response is allelic to the auxin-signaling mutant axr1. Plant Physiol. 2002;130(2):887-94.

48. Wang D, Pajerowska-Mukhtar K, Culler AH, Dong X. Salicylic acid inhibits pathogen growth in plants through repression of the auxin signaling pathway. Cur Biol. 2007;17(20):1784-90.

49. Eshraghi L, Anderson JP, Aryamanesh N, McComb JA, Shearer B, Hardy GS Suppression of the auxin response pathway enhances susceptibility to Phytophthora cinnamomi while phosphite-mediated resistance stimulates the auxin signalling pathway. BMC Plant Biol. 2014;14:68.

50. Evangelisti E, Govetto B, Minet-Kebdani N, Kuhn ML, Attard A, Ponchet M, et al. The Phytophthora parasitica RXLR effector penetration-specific effector 1 favours Arabidopsis thaliana infection by interfering with auxin physiology. New Phytol. 2013;199(2):476-89.

51. Moy P, Qutob D, Chapman BP, Atkinson I, Gijzen M. Patterns of gene expression upon infection of soybean plants by Phytophthora sojae. Mol Plant Microbe Interact. 2004;17(10):1051-62.

52. Foster-Hartnett D, Danesh D, Penuela S, Sharopova N, Endre G, Vandenbosch KA, et al. Molecular and cytological responses of Medicago truncatula to Erysiphe pisi. Mol Plant Pathol. 2007;8(3):307-19.

53. Torregrosa C, Cluzet S, Fournier J, Huguet T, Gamas P, Prosperi JM, et al. Cytological, genetic, and molecular analysis to characterize compatible and incompatible interactions between Medicago truncatula and Colletotrichum trifolii. Mol Plant Microbe Interact. 2004;17(8):909-20.

54. Jaulneau V, Cazaux M, Wong Sak Hoi J, Fournier S, Esquerre-Tugaye MT, Jacquet C, et al. Host and nonhost resistance in Medicago-Colletotrichum interactions. Mol Plant Microbe Interact. 2010;23(9):1107-17.

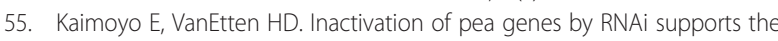
involvement of two similar O-methyltransferases in the biosynthesis of $(+)$-pisatin and of chiral intermediates with a configuration opposite that found in (+)-pisatin. Phytochem. 2008;69(1):76-87.

56. Dubey MK, Ubhayasekera W, Sandgren M, Jensen DF, Karlsson M. Disruption of the Eng18B ENGase gene in the fungal biocontrol agent Trichoderma atroviride affects growth, conidiation and antagonistic ability. PLoS One. 2012;7(5):e36152.

57. Irizarry RA, Hobbs B, Collin F, Beazer-Barclay YD, Antonellis KJ, Scherf U, et al. Exploration, normalization, and summaries of high density oligonucleotide array probe level data. Biostatistics. 2003;4(2):249-64.

58. Team RC. R: A language and environment for statistical computing. Vienna, Austria: R Foundation for Statistical Computing; 2013

59. Oliveros JC. VENNY. An interactive tool for comparing lists with Venn Diagrams. 2007.

60. Seo J, Gordish-Dressman H, Hoffman EP. An interactive power analysis tool for microarray hypothesis testing and generation. Bioinformatics. 2006;22(7):808-14

61. Conesa A, Gotz S, Garcia-Gomez JM, Terol J, Talon M, Robles M. Blast2GO: a universal tool for annotation, visualization and analysis in functional genomics research. Bioinformatics. 2005;21(18):3674-6.

62. Altschul SF, Madden TL, Schaffer AA, Zhang J, Zhang Z, Miller W, et al. Gapped BLAST and PSI-BLAST: a new generation of protein database search programs. Nucleic Acids Res. 1997;25(17):3389-402.

63. Ye J, Fang $L$, Zheng $H$, Zhang $Y$, Chen J, Zhang Z, et al. WEGO: a web tool for plotting GO annotations. Nucleic Acids Res. 2006;34:W293-7. 
64. Moriya Y, Itoh M, Okuda S, Yoshizawa AC, Kanehisa M. KAAS: an automatic genome annotation and pathway reconstruction server. Nucleic Acids Res. 2007;35:W182-5.

65. Kanehisa M, Goto S. KEGG: kyoto encyclopedia of genes and genomes. Nucleic Acids Res. 2000;28(1):27-30.

66. Kanehisa M, Goto S, Sato Y, Furumichi M, Tanabe M. KEGG for integration and interpretation of large-scale molecular data sets. Nucleic Acids Res. 2012:40:D109-14.

67. Hunter S, Apweiler R, Attwood TK, Bairoch A, Bateman A, Binns D, et al. InterPro: the integrative protein signature database. Nucleic Acids Res. 2009;37:D211-5.

68. Livak KJ, Schmittgen TD. Analysis of relative gene expression data using real-time quantitative PCR and the $2^{-\Delta \Delta C T}$ method. Methods. 2001;25(4):402-8.

69. Die JV, Roman B, Nadal S, Gonzalez-Verdejo Cl. Evaluation of candidate reference genes for expression studies in Pisum sativum under different experimental conditions. Planta. 2010;232(1):145-53.

\section{Submit your next manuscript to BioMed Central and take full advantage of:}

- Convenient online submission

- Thorough peer review

- No space constraints or color figure charges

- Immediate publication on acceptance

- Inclusion in PubMed, CAS, Scopus and Google Scholar

- Research which is freely available for redistribution 